\title{
Kilka uwag o epidemiologii nowotworów w Polsce
}

\author{
Witold A. Zatoński, Urszula Sulkowska, Joanna Didkowska
}

W pracy przedstawiono obraz epidemiologiczny nowotworów złośliwych w Polsce, jego zmiany w czasie oraz porównanie z krajami Unii Europejskiej.

Przebieg trendów czasowych umieralności w głównych lokalizacjach nowotworów złośliwych w Polsce jest podobny do obrazu nowotworowego krajów UE. Transformacja epidemiologiczna umieralności z powodu nowotworów w Polsce odbywa się w stosunku do krajów Europy Zachodniej z pewnym opóźnieniem czasowym.

Ogółem trendy epidemiologiczne wszystkich lokalizacji nowotworowych są uśrednieniem rozbieżnych trendów w zachorowaniach na poszczególne nowotwory, często zdominowanym przez zmiany trendów największych lokalizacji nowotworowych. Tak dzieje się np. u mężczyzn w Polsce w przypadku umieralności na nowotwory złośliwe płuca. W drugiej części pracy poddano analizie zjawisko zachorowalności, które także wskazuje na wyraźne zróżnicowanie trendów czasowych poszczególnych lokalizacji. Trendy częstości zachorowań mierzone bezwzględną liczbą nowo diagnozowanych chorób zależą od wielu czynników — środowiskowych czynników ryzyka (np. częstości palenia), które są modyfikowalne, ale także kluczowe znaczenie mają zmiany struktury wieku populacji. Krzywa zachorowań rośnie wykładniczo wraz ze wzrostem długości życia (czynnik niemodyfikowalny). Znaczna większość (60\%) zachorowań na nowotwory złośliwe jest diagnozowana wśród osób po 65 r.ż., a w Polsce obserwuje się stały przyrost ludności w tym wieku.

Trzy zjawiska są najbardziej charakterystyczne dla obrazu trendów czasowych zachorowalności z powodu nowotworów złośliwych w Polsce:

1) gwałtowny spadek zachorowań z powodu nowotworów złośliwych płuca u mężczyzn (po okresie trwającego kilka dekad wzrostu zachorowań);

2) bardzo szybki wzrost zachorowań z powodu nowotworów złośliwych prostaty, szczególnie po 1990 roku;

3) dramatyczny wzrost nowo diagnozowanych nowotworów złośliwych piersi u kobiet, który zdominował zachorowalność na nowotwory złośliwe w Polsce u kobiet (obecnie co czwarty nowo diagnozowany nowotwór u kobiet to nowotwór złośliwy piersi).

Dodatkowo szczegółowej analizie epidemiologicznej poddano kilka głównych lokalizacji nowotworów złośliwych (nowotwory płuca, piersi, gruczołu krokowego, jelita grubego, szyjki macicy i żołądka) oraz przedstawiono ich porównanie z innymi krajami.

Największy sukces w kontrolowaniu nowotworów złośliwych osiągnięto w tych schorzeniach, w których możliwa jest prewencja (przede wszystkim nowotwory złośliwe płuca u mężczyzn), ale także w tych nowotworach, gdzie możliwy jest skuteczny populacyjny skrining (nowotwory złośliwe szyjki macicy, nowotwory złośliwe piersi).

\section{Cancer epidemiology in Poland}

This paper presents the epidemiological picture of cancer in Poland, its changes over time and a comparison with other countries of the European Union (EU). The mortality time trends for the main cancer sites in Poland are similar to those observed in other EU countries. However, the epidemiological transformation in cancer mortality in Poland is delayed with respect to countries of Western Europe. The overall epidemiological trends are an average of the indi- 
vidual trends for different cancers, often dominated by changes in trends for the major cancer sites. This is observed, for example, in the case of male lung cancer mortality in Poland. In the second part of the study we analysed cancer morbidity, which also demonstrated clear differences in time trends in each site. Incidence trends measured by the absolute number of newly diagnosed diseases depend on many factors. The most important factor is the modifiable environmental risk factors (e.g. smoking prevalence), as well as the changes in the age structure the population. The incidence curve grows exponentially with the increase of lifespan (a non-modifiable factor). The vast majority (60\%) of cancer cases are diagnosed among people over 65 years, and in Poland a steady increase of population in this age group is observed.

Three phenomena emerge as the most characteristic of the time trends of cancer morbidity in Poland. (1) A sharp decline in incidence of lung cancer in men (after a period of rising incidence that lasted for decades). (2) Rapid growth in incidence of prostate cancer, especially after 1990. (3) A dramatic increase in newly diagnosed breast cancer cases in women, which dominated the incidence of cancer in women in Poland (currently one in four of newly diagnosed cancers among women is breast cancer).In addition, a detailed epidemiological analysis was conducted for several major cancer sites (lung, breast, prostate, colorectal, cervix and stomach) and its results were compared with trends observed in other countries. The biggest success in cancer control was achieved in those cancer locations, for which prevention is possible (especially lung cancer in men), and also in those cancers, where it is possible to effectively screen a population (cervical cancer, breast cancer).

Słowa kluczowe: epidemiologia nowotworów, umieralność, zachorowalność, Polska, Unia Europejska Key words: cancer epidemiology, mortality, morbidity, incidence, Poland, European Union

Nowotwory Journal of Oncology 2015; 65, 3: 179-196

\section{Przedmowa}

Podczas Warszawskiej Konferencji Onkologicznej, która odbyła się 28 listopada 2014 roku, wygłosiłem wykład pt. "Czy przegrywamy walkę z rakiem - epidemiologia nowotworów złośliwych. Powołanie Narodowego Instytutu Onkologii i Hematologii — warunek konieczny do skutecznej walki z rakiem". Wykład spotkał się z życzliwym zainteresowaniem, ale zorientowałem się, że wiele jego zagadnień wymaga poszerzenia oraz dodatkowych wyjaśnień.

Po moim wykładzie prof. Edward Towpik zaprosił mnie do napisania szerszego opracowania dotyczącego nowotworów złośliwych, ale to wymagało przeprowadzenia dodatkowych analiz.

W międzyczasie Minister Zdrowia powołał Krajową Radę ds. Onkologii, której celem jest przygotowanie strategii walki z rakiem na kolejne 10 lat. Z tego powodu zostałem zobligowany do przedstawienia "tak szybko, jak to możliwe" wstępnego opracowania. Przedstawiony tekst jest skróconą wersją przygotowywanego opracowania, w którym pragnę odpowiedzieć na postawione w wykładzie pytania: co jest możliwe w kontroli nowotworów i jakie powinny być strategiczne priorytety w onkologii zapobiegawczej w Polsce.

Do opracowania wykładu zaprosiłem mgr Urszulę Sulkowską, która razem ze mną przygotowała rysunki i dr. n. med. Joannę Didkowską, która przygotowała przede wszystkim fragment dotyczący chorobowości. Panie Joanna Szwechowicz i Ewa Tarnowska redagowały wraz ze mną tekst i jego formę.
Moi współpracownicy mgr inż. Kinga Janik-Koncewicz i Krzysztof Przewoźniak wspierali mnie w przygotowaniu redakcji niektórych fragmentów tekstu, za co chciałbym im podziękować.

Dziękuję także pani Danucie Sadowskiej-Osmyckiej z redakcji Nowotworów, która wykazała troskę w opracowaniu redakcyjnym. Tekst nie mógłby powstać bez prof. Edwarda Towpika, który nie tylko zaproponował jego temat, ale wspierał i pilnował jego terminowego przygotowania.

\section{Porównanie sytuacji epidemiologicznej w Polsce z krajami Unii Europejskiej}

Trendy czasowe standaryzowanych według wieku współczynników umieralności z powodu nowotworów złośliwych, a szczególnie ich zmiany w czasie, są jednym z najważniejszych, jeżeli nie najważniejszym pojedynczym, syntetycznym wskaźnikiem oceny walki z nowotworami złośliwymi w wymiarze populacyjnym. Dane o umieralności są najdłużej (od początku lat 60.) dostępnymi bazami danych medycznych ${ }^{1}$. Kompletność statystyki zgonów w Polsce WHO ocenia jako bliską 100\%².

Do porównania sytuacji epidemiologicznej w Polsce z krajami Unii Europejskiej wybrano lokalizacje nowotwo-

\footnotetext{
'WHO Mortality Database, http://www.who.int/healthinfo/mortality data/en/.

${ }^{2}$ Mathers CD, Fat DM, Inoue M i wsp. Counting the dead and what they died from: an assessment of the global status of cause of death data. Bull World Health Organ 2005; 83: 171-7. Epub 2005 Mar 16.
} 

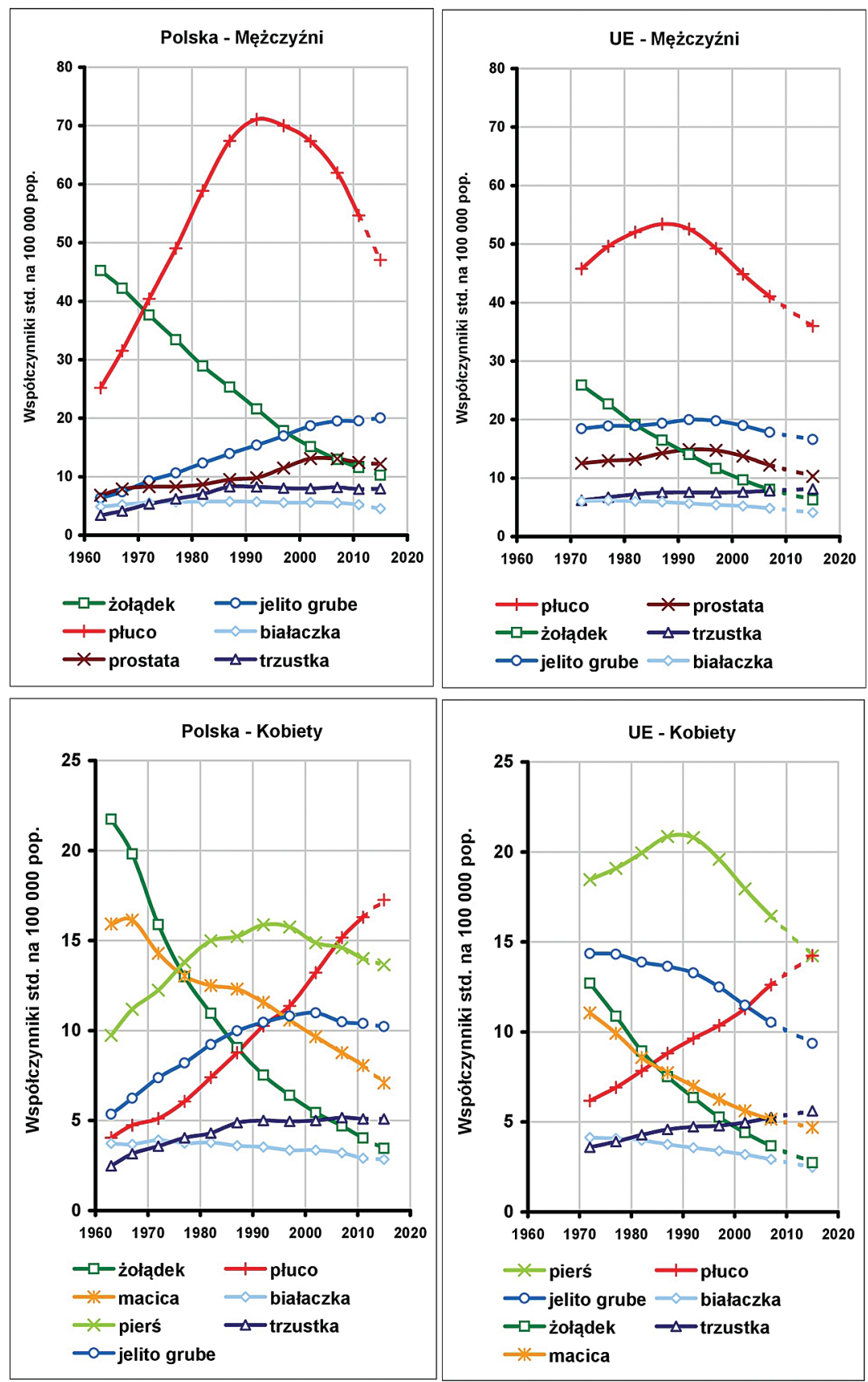

Rycina 1. Trendy czasowe standaryzowanych według wieku współczynników umieralności z powodu wybranych nowotworów złośliwych w Polsce i Unii Europejskiej

Macica obejmuje nowotwory złośliwe szyjki macicy, trzonu macicy i nieokreślonych części macicy

Współczynniki standaryzowane dla pięciolatek zostały obliczone w oparciu o standardową populację świata

Dziękujemy autorom publikacji: Malvezzi M, Bertuccio P, Rosso T i wsp. European cancer mortality predictions for the year 2015: does lung cancer have the highest death rate in EU women? Ann Oncol 2015 Jan 26. pii: mdv001 za udostępnienie danych potrzebnych do przygotowania trendów dla UE.

Trendy czasowe i prognoza dla Polski i Unii Europejskiej do 2015 roku obliczone na podstawie danych dla UE do 2009 r.; ostatnie dane dla Polski z 2012 r.

rowe z ostatnio opublikowanej pracy zespołu prof. Carlo La Vecchii, jednego z największych autorytetów epidemiologii nowotworów złośliwych w Europie ${ }^{3}$. Umieralność w Unii

${ }^{3}$ Malvezzi M, Bertuccio P, Rosso T i wsp. European cancer mortality predictions for the year 2015: does lung cancer have the highest death rate in EU women? Ann Oncol 2015; 26: 779-86. doi: 10.1093/annonc/mdv001. Epub 2015 Jan 26.
Europejskiej (średnia z 27 krajów) porównano z wynikami analizy przeprowadzonej dla Polski w oparciu o taką samą metodę i dla tych samych lokalizacji ${ }^{4}$, co zostało przedstawione na rycinie 1.

${ }^{4}$ Dziękujemy autorom publikacji za przygotowanie i udostępnienie danych dla UE oraz prognoz dla Polski. 


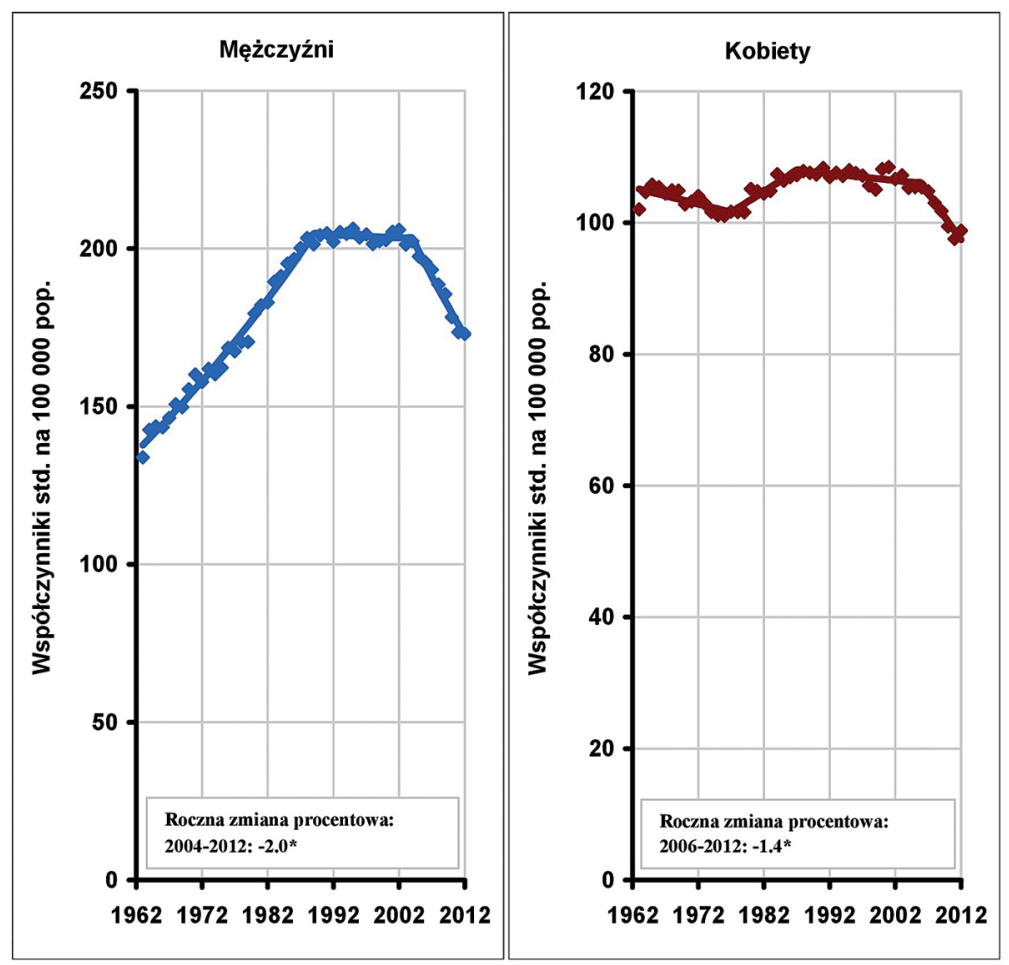

Rycina 2. Trendy czasowe standaryzowanych według wieku współczynników umieralności z powodu nowotworów złośliwych ogółem w Polsce,

1963-2012

Współczynniki standaryzowane zostały obliczone w oparciu o standardową populację świata

*Zmiana istotnie statystycznie różna od zera.

W ostatnich latach obserwuje się istotny statystycznie spadek umieralności z powodu nowotworów złośliwych ogółem, zarówno u mężczyzn, jak i u kobiet.

Sześć głównych lokalizacji nowotworowych, zarówno u mężczyzn, jak i u kobiet, stanowi ponad $60 \%$ całej umieralności z powodu nowotworów złośliwych. Pozostałe 40\% umieralności to znacznie mniejsze liczbowo lokalizacje nowotworowe (liczba różnych lokalizacji i form pozostałych nowotworów jest opisana na ponad 200), wiele z nich to schorzenia rzadkie (mniej niż 5 przypadków na 10000 populacji) lub bardzo rzadkie.

Obraz współczynników umieralności nowotworów złośliwych w Polsce, zarówno jeżeli chodzi o ich strukturę, jak i trendy czasowe, jest podobny do obrazu nowotworowego innych krajów UE. Generalnie trendy epidemiologiczne są w Polsce przesunięte w czasie (podobnie, jak w innych krajach wschodniej części EU).

Częstość dwóch największych lokalizacji nowotworowych - nowotworów złośliwych żołądka i nowotworów złośliwych płuca — zdecydowała, że Polska należała i należy do krajów o najwyższym ryzyku zgonów z powodu nowotworów złośliwych. Najpierw, w połowie XX wieku, umieralność na nowotwory złośliwe żołądka w Polsce należała do najwyższych w Europie. Następnie, pod koniec XX wieku, umieralność na nowotwory złośliwe płuca u mężczyzn stała się jedną z najwyższych na naszym kontynencie.
W ostatnich dziesięcioleciach istotną różnicą w przebiegu trendów czasowych nowotworów złośliwych w Polsce w porównaniu z sytuacją epidemiologiczną w krajach Europy zachodniej, ale także w USA, jest kierunek trendu czasowego umieralności z powodu nowotworów jelita grubego. Podobnie spadkowy trend czasowy współczynników umieralności z powodów nowotworów złośliwych piersi u kobiet zaczął się w Polsce później i jest wolniejszy niż w zachodniej części Unii Europejskiej.

Na koniec trzeba też zwrócić uwagę na ograniczoną wartość i potrzebę ostrożnej interpretacji analizy epidemiologicznej łącznie wszystkich lokalizacji nowotworowych. Trendy epidemiologiczne ogółem wszystkich lokalizacji nowotworowych są tylko uśrednieniem rozbieżnych trendów poszczególnych lokalizacji, często zdominowanym przede wszystkim przez zmiany trendów największych lokalizacji nowotworowych (ryc. 2), tak jak to się dzieje np. u mężczyzn w Polsce w przypadku nowotworów złośliwych płuca w ostatnim dziesięcioleciu.

\section{Zachorowania na nowotwory złośliwe}

Kolejnym fundamentalnym wskaźnikiem opisującym sytuację epidemiologiczną nowotworów złośliwych jest zachorowalność. Generalnie obserwuje się, podobnie jak w przypadku umieralności, zróżnicowane kierunki (spadek 

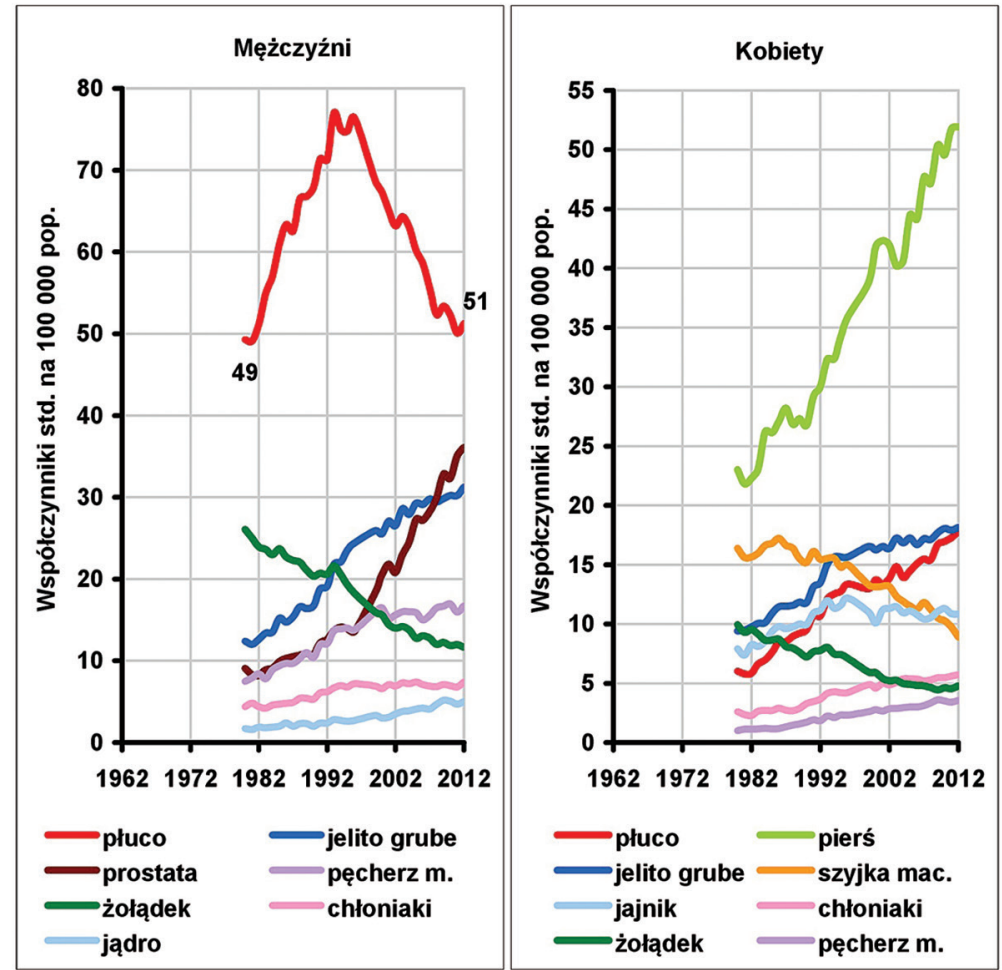

Rycina 3. Trendy czasowe standaryzowanych według wieku współczynników zachorowalności na wybrane nowotwory złośliwe w Polsce, 1980-2012

Współczynniki standaryzowane zostały obliczone w oparciu o standardową populację świata Niedorejestrowanie zachorowań na nowotwory złośliwe w Polsce szacowano na $30 \%$ na początku lat 80., a w 2011 r. niedorejestrowanie w skali kraju wyniosło 6\%. (Źródło: Didkowska J, Wojciechowska U, Zatoński W. Nowotwory złośliwe w Polsce w 2011 roku. Warszawa: Krajowy Rejestr Nowotworów, Centrum Onkologii — Instytut im. Marii Skłodowskiej-Curie; 2013).

W obrazie zachorowalności u mężczyzn dominuje spadek współczynników zachorowań z powodu nowotworów złośliwych płuca, a u kobiet wzrost współczynników zachorowań na nowotwory złośliwe piersi.
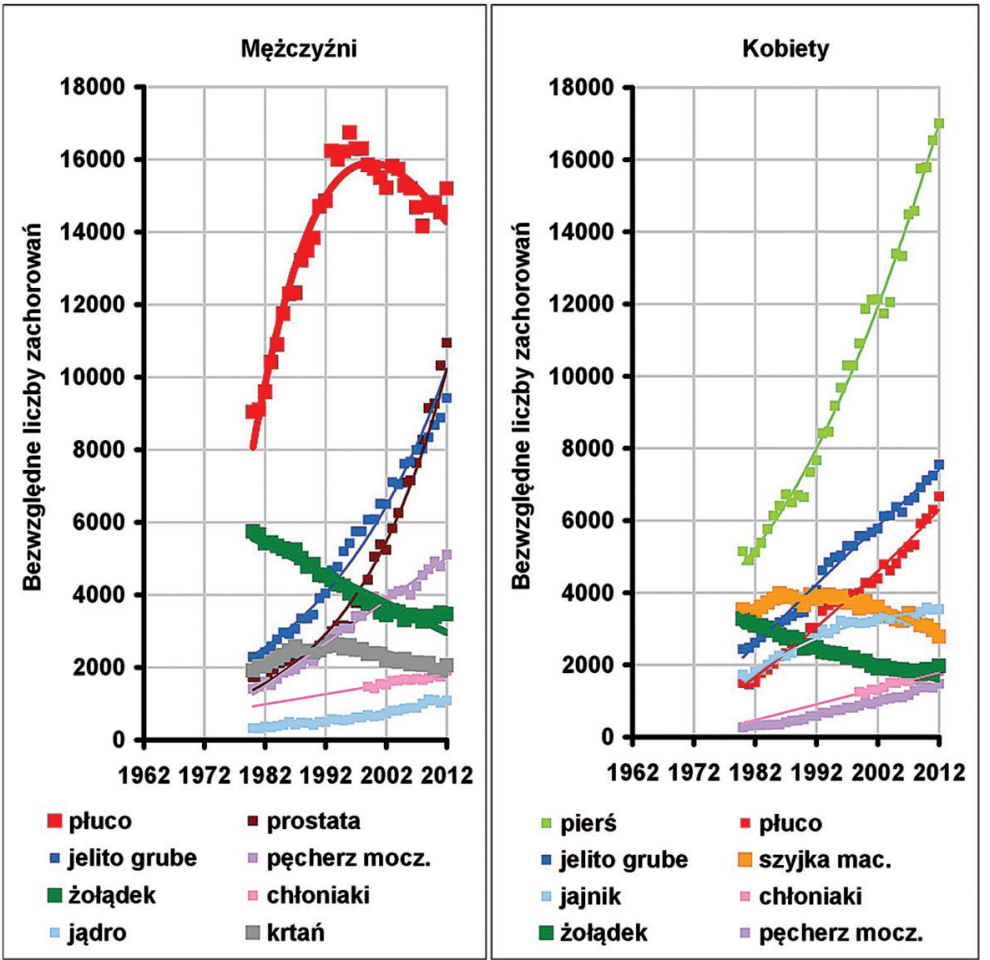

Rycina 4. Liczby bezwzględne nowo diagnozowanych zachorowań na wybrane nowotwory złośliwe w Polsce, 1980-2012 Niedorejestrowanie zachorowań na nowotwory złośliwe w Polsce szacowano na 30\% na początku lat 80., a w 2011 r. niedorejestrowanie w skali kraju wyniosło 6\%. (Źródło: Didkowska J, Wojciechowska U, Zatoński W. Nowotwory złośliwe w Polsce w 2011 roku. Warszawa: Krajowy Rejestr Nowotworów, Centrum Onkologii — Instytut im. Marii Skłodowskiej-Curie; 2013).

Obserwuje się spadek liczby nowych zachorowań na nowotwory złośliwe płuca, żołądka i krtani u mężczyzn oraz nowotwory złośliwe żołądka i szyjki macicy u kobiet.

i wzrost) trendów czasowych poszczególnych lokalizacji i form nowotworów złośliwych (ryc. 3, 4).

Trzy zjawiska są najbardziej charakterystyczne dla obrazu trendów czasowych zachorowalności z powodu nowotworów złośliwych w Polsce:
1) gwałtowny spadek zachorowań z powodu nowotworów złośliwych płuca u mężczyzn (po okresie trwającego kilka dekad wzrostu zachorowań);

2) bardzo szybki wzrost zachorowań z powodu nowotworów złośliwych prostaty, szczególnie po 1990 roku; 
3) dramatyczny wzrost nowo diagnozowanych nowotworów złośliwych piersi u kobiet, który zdominował zachorowalność na nowotwory złośliwe w Polsce u kobiet (obecnie co czwarty nowo diagnozowany nowotwór u kobiet to nowotwór złośliwy piersi).

Główne lokalizacje zachorowań na nowotwory złośliwe stanowią około $60 \%$ wszystkich zachorowań u obu płci, przy czym w przypadku zachorowalności, obok częstości zachorowań (wyrażonych we współczynnikach standaryzowanych według wieku) opisujących zjawisko, niezmiernie istotna jest liczba zachorowań (liczba rozpoznawanych corocznie nowotworów złośliwych). Jest to niezwykle ważna informacja dla funkcjonowania systemu diagnostyki, leczenia i opieki onkologicznej, jej prowadzenia i planowania.

Trzeba także wspomnieć, że w przypadku liczby nowo diagnozowanych nowotworów złośliwych (ryc. 5) oprócz zmiany ekspozycji na środowiskowe czynniki ryzyka (np. wzrostu czy spadku częstości palenia) kluczowym czynnikiem kształtującym liczbę zachorowań na nowotwory złośliwe w populacji jest zmiana jej struktury wieku, wynikająca ze zwiększającej się długości życia.

Większość nowotworów złośliwych charakteryzuje się długim okresem latencji, liczonym w dziesięcioleciach od chwili rozpoczęcia ekspozycji na czynnik rakotwórczy (na przykład od rozpoczęcia palenia) do chwili pojawienia się objawów schorzenia. Nowotworowe przekształcenie zdrowej komórki odbywa się w wyniku mutacji genetycznej. Zmiana w DNA może być wywołana działaniem czynnika mutagennego, np. dymu tytoniowego czy wirusów. Ale są też inne przyczyny, coraz częściej przypominane i dyskutowane ${ }^{5}$, powstawania nowotworów złośliwych, tzw.,,mutacja spontaniczna" ${ }^{6}$ czy predyspozycje genetyczne, szacowane jako przyczyna 5-10\% wszystkich zachorowań na nowotwory. Zmutowana nowotworowo komórka musi dodatkowo, w trakcie niezliczonej liczby podziałów, przełamać system genów obronnych. Dopiero wtedy mamy do czynienia z rozwojem choroby nowotworowej przechodzącej do fazy klinicznej. Te cechy chorób nowotworowych prowadzą do liniowej zależności częstości zachorowań od długości ekspozycji, która jest funkcją przyrostu wieku. Krzywa umieralności z powodu nowotworów złośliwych rośnie wykładniczo wraz ze wzrostem długości życia. Dla grupy wiekowej 0-19 lat częstość wynosi od 1 do 9 zgonów na 100000 populacji. W grupie wiekowej 20-44 lat — od 10 do 99 zgonów na 100000 populacji. W grupie wiekowej 45-64 — od 100 do 999 zgonów na 100000 populacji. W grupie wiekowej 65+ występuje od 1000 do 10000 i więcej zgonów na 100000 populacji.

\footnotetext{
${ }^{5}$ Peto R, Roe FJ, Lee PN i wsp. Cancer and ageing in mice and men. Br J Cancer 1975; 32: 411-426.

${ }^{6}$ Tomasetti C,Vogelstein B. Cancer etiology. Variation in cancer risk among tissues can be explained by the number of stem cell divisions. Science
} 2015; 347: 78-81.

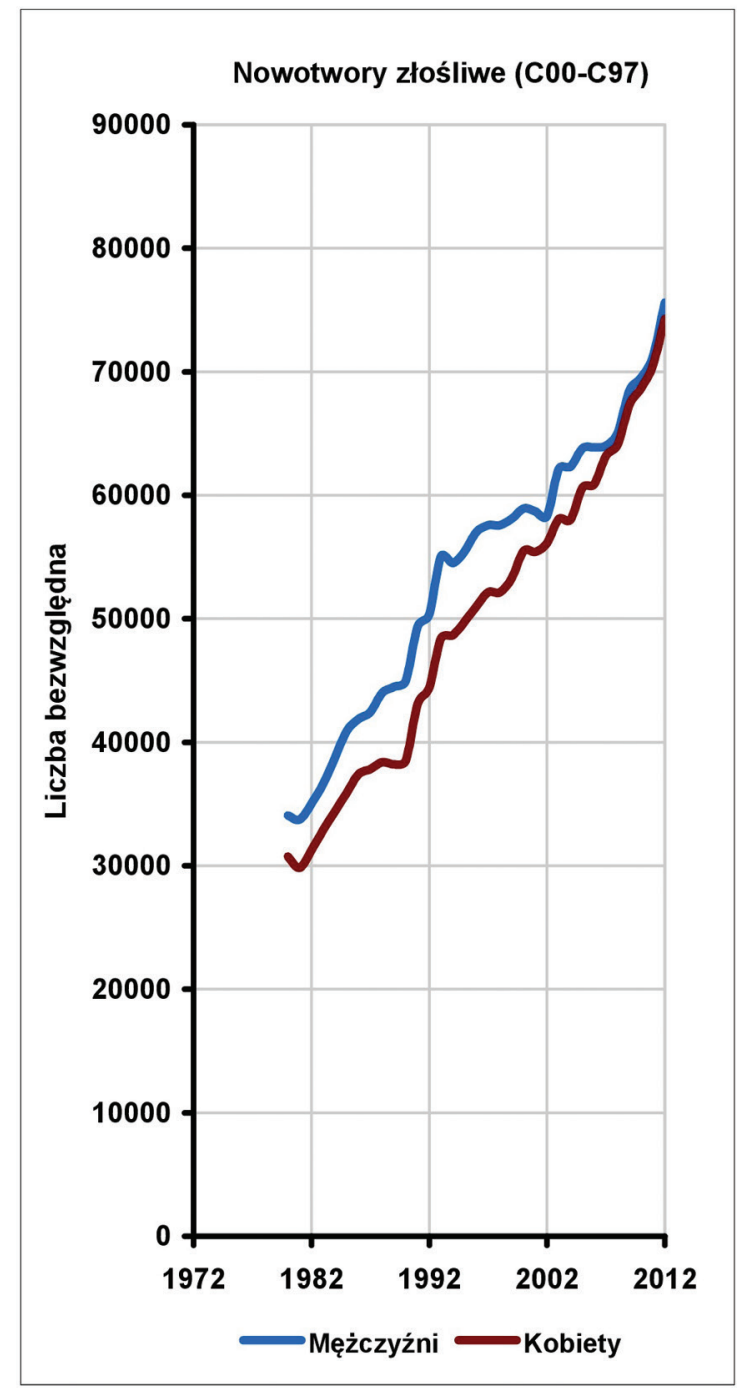

Rycina 5. Zmiana w czasie rejestrowanej bezwzględnej liczby zachorowań na nowotwory złośliwe ogółem w Polsce w latach 1980-2012

Niedorejestrowanie zachorowań na nowotwory złośliwe w Polsce szacowano na 30\% na początku lat 80., a w 2011 r. niedorejestrowanie w skali kraju wyniosło 6\%. (Źródło: Didkowska J, Wojciechowska U, Zatoński W. Nowotwory złośliwe w Polsce w 2011 roku. Warszawa: Krajowy Rejestr Nowotworów, Centrum Onkologii — Instytut im. Marii Skłodowskiej-Curie; 2013).

Przez cały okres obserwacji liczba nowo rozpoznawanych nowotworów stale, corocznie wzrasta.

Większość zachorowań na nowotwory złośliwe (60\%) diagnozowana jest u osób po 65 r.ż. Wynika to z rosnącej w ostatnim 25-leciu oczekiwanej długości życia w Polsce i stałego przyrostu ludności z tej grupy wieku.

Aby zrozumieć istniejące obecnie możliwości prewencji pierwotnej, analiza trendów czasowych głównych lokalizacji nowotworowych w Polsce została przeprowadzona osobno w dwóch grupach w zależności od obserwowanego trendu czasowego zachorowań:

1) spadek zachorowalności,

2) wzrost zachorowalności. 


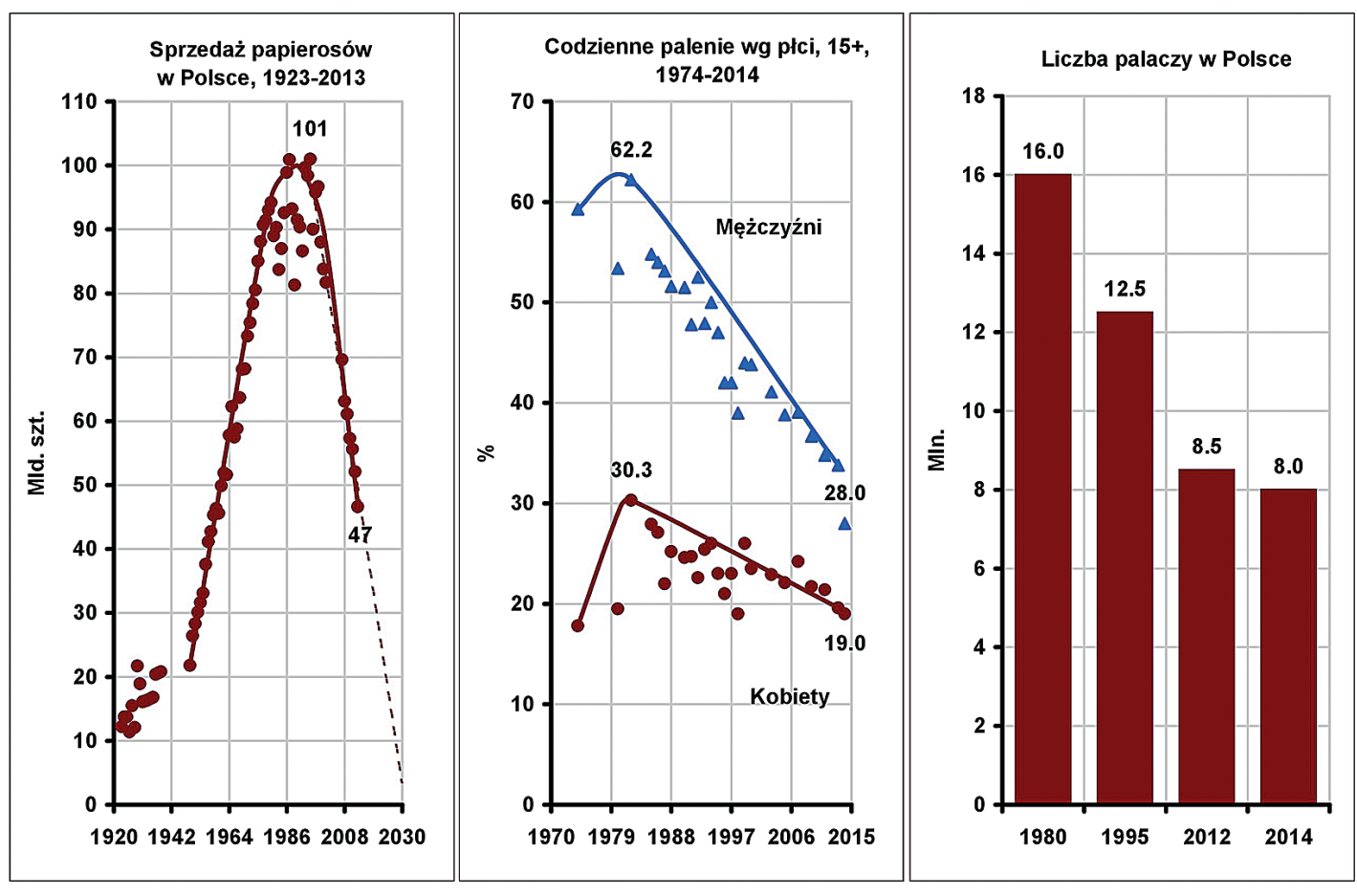

Rycina 6. Liczba palaczy, sprzedaż i spożycie papierosów per capita w Polsce

Źródło: Zatoński W, Przewoźniak K, Sulkowska U i wsp. Tobacco smoking in countries of the European Union. Ann Agric Environ Med. 2012; 19: 181-92.; Czapiński J, Panek T. (red.). Diagnoza Społeczna 2013.

W Polsce od połowy lat 90. spada w szybkim tempie sprzedaż papierosów, obserwuje się także istotną zmianę w częstości palenia kobiet i mężczyzn. Liczba palaczy w Polsce obniżyła się o połowę na przestrzeni ostatnich 35 lat.

\section{Spadek zachorowalności}

Spadek częstości zachorowań obserwuje się u mężczyzn w prawie co trzeciej lokalizacji nowotworowej (około 30\%) i co szóstej (ponad 15\%) lokalizacji nowotworowej u kobiet. Są to lokalizacje nowotworowe o zwykle znanej etiologii oraz takie, gdzie istnieją skuteczne metody prewencji?.

Spadek zachorowalności z powodu nowotworów złośliwych płuca (i innych tytoniozależnych lokalizacji) jest spowodowany zmniejszającą się ekspozycją na czynniki rakotwórcze dymu papierosowego, co ilustruje spadek konsumpcji papierosów, stałe zmniejszanie się częstości palenia i liczby palaczy w populacji Polski (ryc. 6). Spadek zachorowań w tej grupie nowotworów dotyczy przede wszystkim populacji mężczyzn.

Także zachorowania i umieralność z powodu nowotworów złośliwych szyjki macicy, również w ostatnim dziesięcioleciu (przesunięte w czasie w stosunku do krajów Europy Zachodniej), wykazują znaczący spadek. Spadek zachorowalności i umieralności wynika z prewencji pierwotnej, wczesnej diagnostyki (populacyjne badania przesiewowe) oraz skutecznego leczenia.

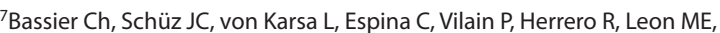
Minozzi S, Romieu I, Segnan N, Wardle J, Wiseman M, Belardelli F, Bettcher DW, Cavalli F, Galea G, Lenoir G, Martin-Moreno JM, Nicula FA, Olsen JH, Patnick J, Primic-Zakelj M, Puska P, van Leeuwen FE, Wiestler O, Zatonski W. European code against cancer. 4th edition: 12 ways to reduce your cancer risk. Cancer Epidemiology (wysłane do publikacji).
Podobnie od wielu dziesięcioleci spadają zachorowania (i wynikająca z nich umieralność) na nowotwory złośliwe żołądka. Przyczyn tego, mającego miejsce w całej Europie, zjawiska upatruje się $\mathrm{m}$. in. w zmianie diety (szczególnie we wzroście spożycia warzyw i owoców) oraz w technikach przechowywania żywności (lodówki), a także, być może, lepszej, skuteczniejszej kontroli infekcji Helicobacter pylori — chociaż przyczyny tego zjawiska są nie do końca wyjaśnione.

Reasumując, spadek częstości zachorowań na nowotwory złośliwe jest nie tylko możliwy, ale ma miejsce także w Polsce. Zjawisko to dotyczy nowotworów, których przyczyna i mechanizm powstawania jest znany oraz istnieją możliwości skutecznej interwencji.

\section{Wzrost zachorowalności}

Wśród najliczniejszych lokalizacji nowotworowych gwałtownie przyrastają nowo diagnozowane zachorowania z powodu nowotworów złośliwych piersi u kobiet i nowotwory złośliwe prostaty u mężczyzn. Podobnie stale, chociaż nie tak gwałtownie, wzrastają zachorowania z powodu nowotworów złośliwych jelita grubego u obu płci. Czerniak złośliwy i nowotwory złośliwe jądra także wykazują niezwykle szybki przyrost zachorowań.

Niestety, w dużej grupie lokalizacji wiedza o ich przyczynach oraz możliwości ich prewencji pierwotnej i wtórnej są stale niewystarczające. Przyczyny wzrostu 

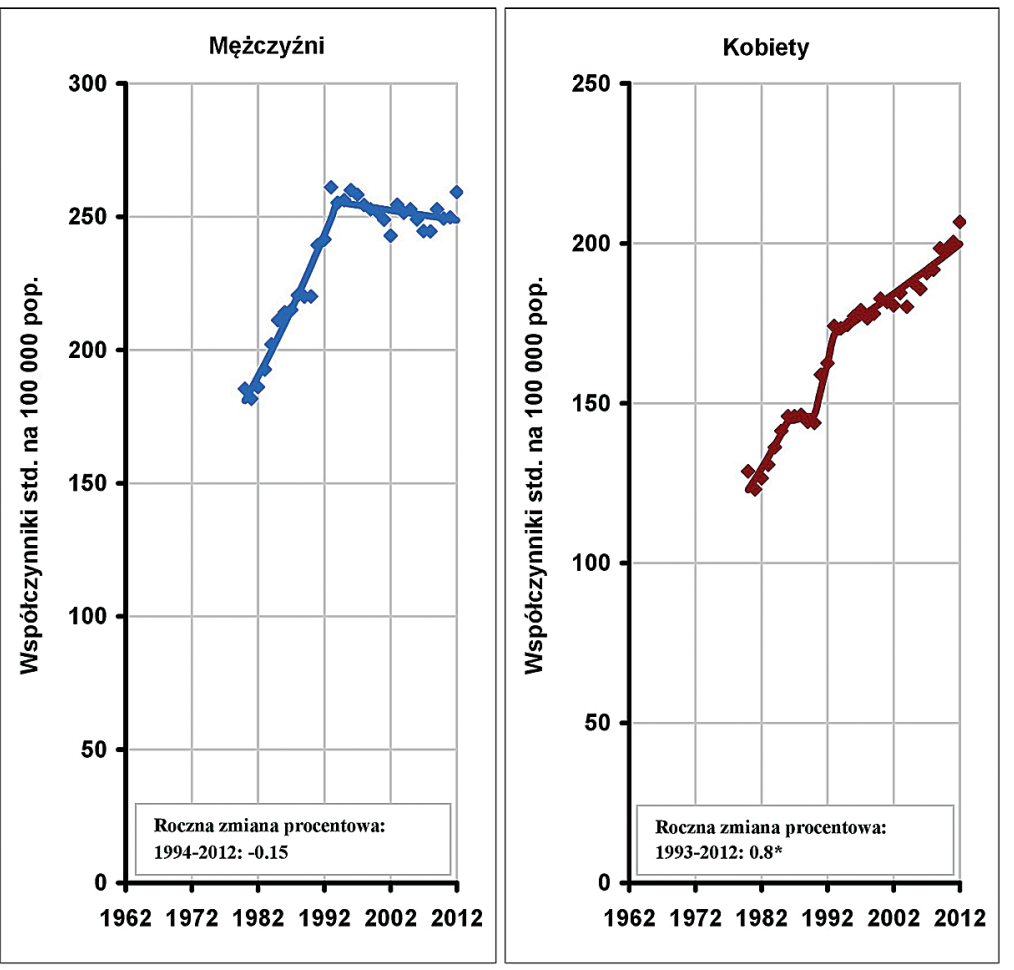

Rycina 7. Trendy czasowe standaryzowanych według wieku współczynników zachorowalności na nowotwory złośliwe ogółem w Polsce, 1980-2012 Współczynniki standaryzowane zostały obliczone w oparciu o standardową populację świata Niedorejestrowanie zachorowań na nowotwory złośliwe w Polsce szacowano na $30 \%$ na początku lat 80., a w 2011 r. niedorejestrowanie w skali kraju wyniosło 6\%. (Źródło: Didkowska J, Wojciechowska U, Zatoński W. Nowotwory złośliwe w Polsce w 2011 roku. Warszawa: Krajowy Rejestr Nowotworów, Centrum Onkologii — Instytut im. Marii Skłodowskiej-Curie; 2013).

*Zmiana istotnie statystycznie różna od zera. W ostatnim dwudziestoleciu obserwuje się zahamowanie wzrostu i tendencję spadku zachorowalności na nowotwory złośliwe ogółem u mężczyzn oraz istotny statycznie wzrost zachorowalności wśród kobiet.

zachorowań są różnorodne. Mogą wynikać ze zmiany struktury demograficznej populacji, co zostało już szerzej omówione. Także wcześniejsze rozpoznania wynikające z nowych i udoskonalanych metod diagnostycznych nie są prawdopodobnie bez znaczenia.

Podobnie jak w przypadku umieralności, trendy współczynników zachorowalności ogółem są tylko uśrednioną wartością różnokierunkowych trendów poszczególnych nowotworów (ryc. 7). Tak na przykład obserwowane w ostatnich dziesięcioleciach trendy zachorowalności nowotworów złośliwych u kobiet są przede wszystkim wynikiem wzrostu liczby zdiagnozowanych nowotworów złośliwych piersi, a zatrzymanie od początku lat 90. wzrostu współczynników zachorowań ogółem u mężczyzn wynika przede wszystkim ze spadku zachorowań z powodu nowotworów złośliwych płuca.

Liczba corocznie rozpoznawanych nowotworów złośliwych jest sumą liczby przypadków poszczególnych lokalizacji nowotworowych, które wykazują zarówno wzrosty, jak i spadki zachorowań. W rezultacie obserwuje się jednak stały wzrost liczby bezwzględnej nowych zachorowań nowotworowych (ryc. 5). Od początku lat 80. liczba nowo rozpoznanych zachorowań na nowotwory złośliwe wzrosła z ok. 70000 do ok. 150000 przypadków u obu płci na początku I dekady XXI wieku. Od 2007 roku liczba zachorowań u mężczyzn i kobiet jest prawie identyczna, a w ostatnich 6 latach liczba zachorowań u kobiet nieznacznie przekracza liczbę zachorowań u mężczyzn. W latach 2000-2012 liczba zachorowań wśród mężczyzn wzrosła o 29\%, wśród kobiet o 37\%. Wzrost liczby zachorowań dotyczy przede wszystkim osób w średnim (45-64 lata) i w starszym wieku (powyżej 65+).

\section{Chorobowość 5-letnia w latach 2006 i 2012}

Chorobowość 5-letnia jest miarą, która określa liczbężyjących chorych z rozpoznaniem nowotworu zdiagnozowanym w ciągu poprzedzających 5 lat. W 2006 roku chorobowość 5-letnią oszacowano na 323 tys., w 2012 roku wynosiła ona już 364 tys. Wzrosła również chorobowość wyrażona jako współczynnik na 100 tys. populacji z 847/100,000 do 945/100 000.

Według oszacowań chorobowości przeprowadzonych dla 2012 roku European Cancer Observatory w Polsce wskaźnik ten jest niższy niż w większości krajów europejskich (ryc. 8).Wskaźnik ten jest pochodną struktury nowotworów złośliwych w danym kraju, częstości zachorowań, wczesnej diagnozy i skuteczności leczenia.

\section{Charakterystyka epidemiologiczna wybranych nowotworów złośliwych i porównania międzynarodowe}

\section{Nowotwory płuca}

Nowotwór złośliwy płuca to najczęstszy nowotwór w populacji mężczyzn (stanowi około 20\% zachorowań i około 30\% zgonów), który od prawie dwóch dekad charakteryzuje się malejącą tendencją (ryc. 9). Zjawisko to jest konsekwencją spadającej częstości palenia tytoniu wśród mężczyzn we wszystkich grupach wieku w Polsce. 


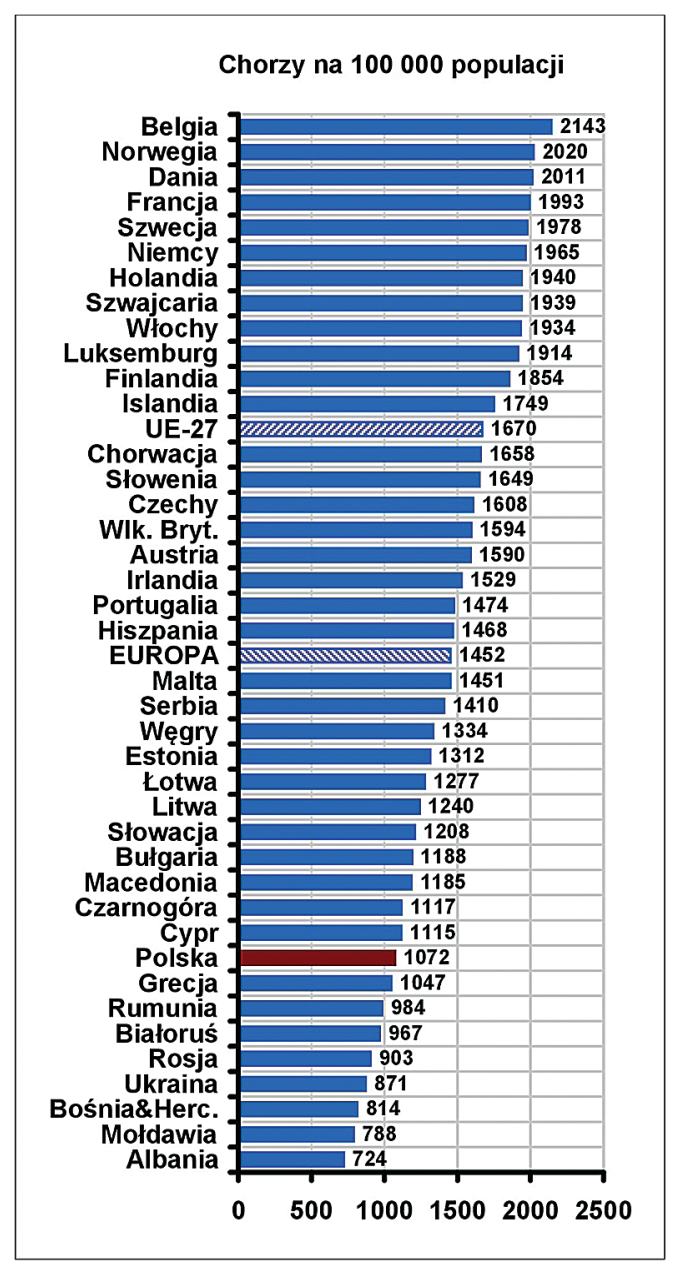

Rycina 8. Chorobowość 5-letnia

Źródło: European Cancer Observatory 2012, http://eco.iarc. fr/EUCAN/Cancer.aspx?Cancer $=0$.

Liczba chorych na 100000 populacji w Polsce jest jedną z najniższych w UE.

Inaczej wygląda sytuacja u kobiet, gdzie aktywne palenie tytoniu jest bardzo zróżnicowane przez efekt kohorty (okres urodzenia w czasie kalendarzowym). Historycznie najwyższy poziom palenia obserwuje się w pokoleniu kobiet urodzonych między 1940 a 1960 rokiem, które wchodziły w dorosłość w latach 1960-1980 — wynosił on w niektórych okresach nawet $50 \%$. W populacji kobiet urodzonych po 1960 r. częstość palenia jest o połowę niższa i wynosi 20-25\%. Ekspozycja na czynniki rakotwórcze dymu tytoniowego po uwzględnieniu 20-letniego okresu latencji dobrze przystaje i wyjaśnia trendy nowotworów złośliwych płuca u kobiet w różnych grupach wieku i czasie. Obserwowany efekt kohorty jest przyczyną tego, że zachorowania (i wynikająca z nich umieralność) ciągle wykazują tendencję wzrostową, która będzie utrzymywała się jeszcze przez pewien czas $^{8}$.

${ }^{8}$ Zatoński W, Sulkowska U, Przewoźniak K. Epidemiologia nowotworów złośliwych w Polsce. GUS Rządowa Rada Ludnościowa. 2014, s. 30-49.
W konsekwencji nowotwór złośliwy płuca od siedmiu lat jest pierwszą nowotworową przyczyną zgonów u kobiet! Z drugiej strony w najmłodszych kohortach urodzeniowych, u młodych i w średnim wieku dorosłych kobiet, od pewnego czasu obserwuje się już spadek zachorowalności i umieralności ${ }^{9}$ (ryc. 9).

W 2012 roku na nowotwory złośliwe płuca zachorowało prawie 22 tys. osób - 15,2 tys. mężczyzn i 6,7 tys. kobiet, a umarło ponad 22,6 tys. osób - w tym ok. 16,2 tys. mężczyzn i ponad 6,4 tys. kobiet.

Nowotwory złośliwe płuca są jedną z lokalizacji, która dominuje w obrazie nowotworowym w Polsce. Wiedza o ich etiologii, przebiegu oraz możliwości kontroli jest bardzo obszerna. W przypadku tych schorzeń istnieje znaczna możliwość modyfikacji zagrożenia. W Polsce szacuje się frakcję zachorowalności na nowotwory płuca wynikającą z palenia (Tobacco Attributable Fraction) na około 80-90\% u mężczyzn i około $60-70 \%$ u kobiet ${ }^{10}$. Wśród osób niepalących poziom zachorowań na nowotwory złośliwe płuca jest bardzo niski i wynosi poniżej 5 zachorowań na 100000 populacji ${ }^{11}$.

W ostatnim półwieczu nie obserwuje się przełomu w leczeniu tej lokalizacji nowotworowej. Na początku XXI wieku najskuteczniejszą interwencją zmniejszającą zagrożenie tym nowotworem jest eradykacja palenia tytoniu. Skuteczność i możliwości tej interwencji potwierdzają także nasze doświadczenia i porównanie obrazu epidemiologicznego w Polsce z innymi krajami (ryc. 10, 11).

\section{Nowotwory piersi}

Nowotwór złośliwy piersi jest najczęstszym nowotworem występującym u kobiet - w 2012 roku odnotowano 17 tys. zachorowań. W ostatniej dekadzie obserwuje się w Polsce gwałtowny wzrost zachorowalności na nowotwory piersi, przy czym głównie wśród kobiet między 50 a 69 rokiem życia. Wzrostowi zachorowalności nie towarzyszy wzrost umieralności - w ostatnim dwudziestoleciu obserwuje się wyraźną tendencję spadkową umieralności u kobiet przed 50 r.ż i słabszą, ale istotną statystycznie u kobiet w wieku 50-69 lat (ryc. 12). W 2012 r. z powodu nowotworów złośliwych piersi zmarło ponad 5,5 tys. kobiet.

Wprowadzenie nowych technik wczesnej diagnostyki nowotworów piersi u kobiet - zakup nowoczesnych urządzeń mammograficznych charakteryzujących się dużą czułością i swoistością i liczony w setki tysięcy wzrost liczby wykonywanych mammografii w populacji zdrowych kobiet - doprowadziło do bardzo istotnych zmian obrazu nowotworów piersi u kobiet w Polsce.

\footnotetext{
9Didkowska J, Manczuk M, McNeill A, Powles J, Zatoński W. Lung cancer mortality at ages 35-54 in the European Union: ecological study of evolving tobacco epidemics. British Medical Journal 2005; 331: 189-191. ${ }^{10}$ Zatoński WA, Manczuk M, Powles P i wsp. Convergence of male and female lung cancer mortality at younger ages in the European Union and Russia. Eur J Public Health 2007; 17: 450-454.

${ }^{11}$ Thun MJ, Henley SJ, Burns D i wsp. Lung cancer death rates in lifelong non-smokers. J Natl Cancer Inst 2006; 98: 691-699.
} 

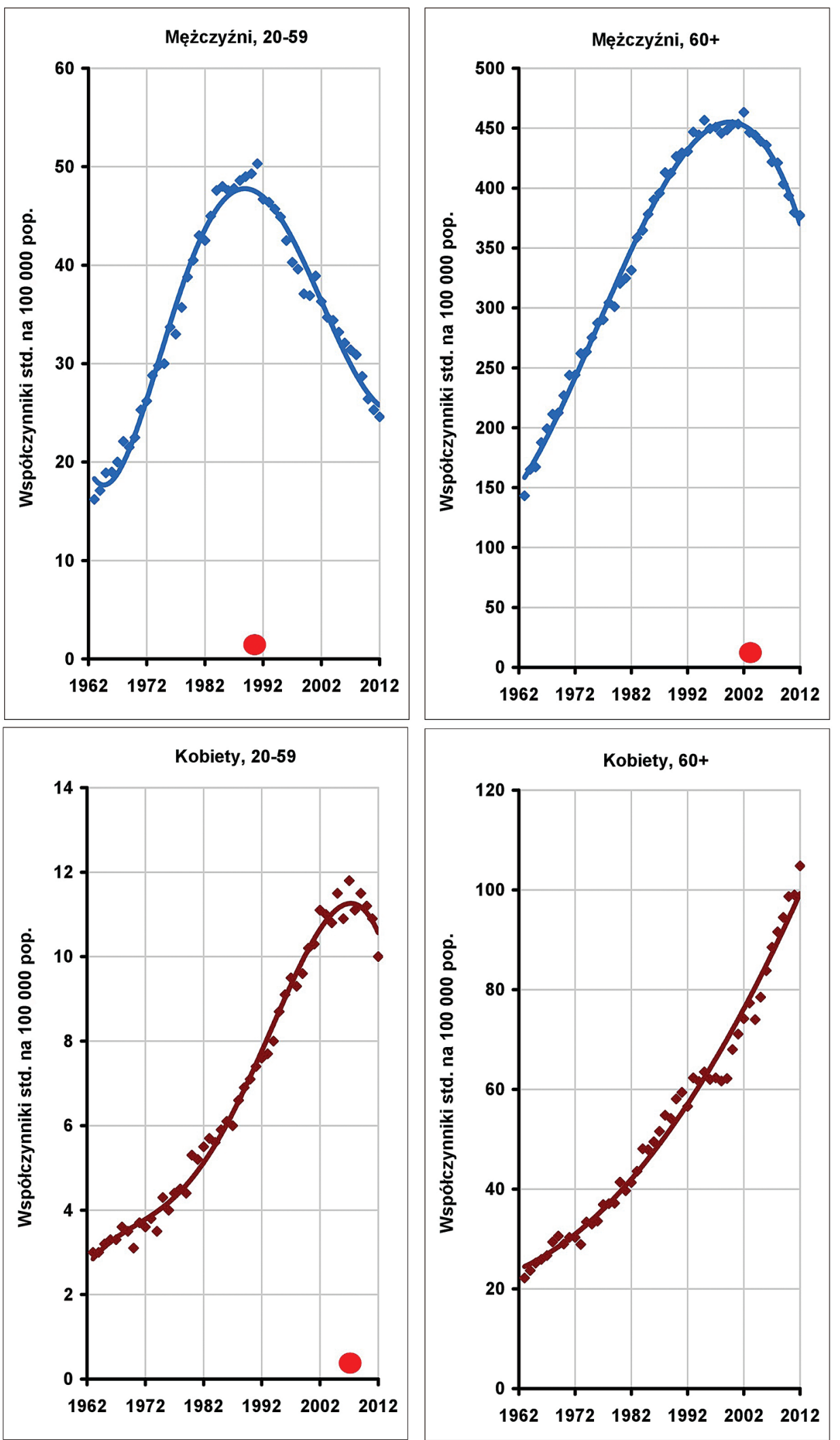

Rycina 9. Trendy czasowe standaryzowanych według wieku współczynników umieralności z powodu nowotworów złośliwych płuca w Polsce w grupach wieku

Współczynniki standaryzowane zostały obliczone w oparciu o standardową populację świata

Od początku lat 90. obserwuje się istotny spadek umieralności z powodu nowotworów złośliwych płuca u mężczyzn w wieku 20-59 lat, a od 2000 r. spadek także wśród mężczyzn po 60 r.ż. Umieralność kobiet między 20 a 59 r.ż. dopiero w ostatniej dekadzie osiągnęła szczyt, i obecnie wykazuje tendencję spadkową. Umieralność wśród kobiet po 60 r.ż. wciąż istotnie rośnie. 


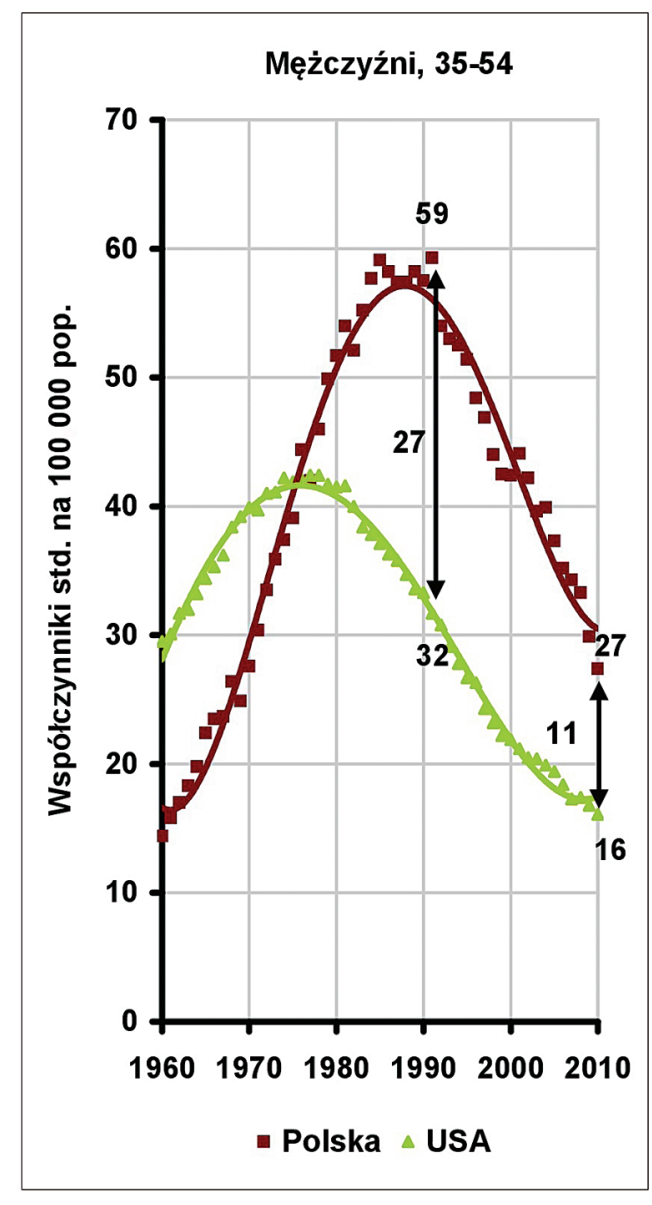

Rycina 10. Trendy czasowe standaryzowanych według wieku współczynników umieralności z powodu nowotworów złośliwych płuca w Polsce i USA

Współczynniki standaryzowane zostały obliczone w oparciu o standardową populację świata

Szczyt umieralności wśród młodych mężczyzn w Polsce był znacząco wyższy niż w USA i przesunięty w czasie o około 20 lat. Spadek umieralności od lat 90 . jest podobny do obserwowanego w Stanach Zjednoczonych i ma stałe dobre tempo — różnice zmniejszają się.

Znacząco wzrosła liczba wcześnie rozpoznawanych nowotworów piersi - w ostatniej dekadzie z 11000 do prawie $17000^{12}$. Trend spadku umieralności z powodu nowotworów piersi będzie najprawdopodobniej utrwalać się w Polsce w najbliższym dziesięcioleciu, jak to ma miejsce winnych krajach (ryc. 13). Niestety, wskaźniki epidemiologiczne takie jak rozejście się trendów czasowych zachorowalności i umieralności zdają się wskazywać na rosnące zjawisko nadrozpoznawalności.

\section{Nowotwory gruczołu krokowego}

Nowotwór złośliwy gruczołu krokowego jest drugim co do częstości zachorowań nowotworem w Polsce (prawie 11 tys. zachorowań w 2012 roku) i trzecią nowotworową

\footnotetext{
${ }^{12}$ Zatoński WA. Powołanie Narodowego Instytutu Onkologii i Hematologii — warunek konieczny do skutecznej walki z rakiem w Polsce. Nowotwory J Oncol 2013; 63; 5: 375-381.
}

przyczyną zgonu (około 4,2 tys. zgonów). Częstość rozpoznawania tego schorzenia gwałtownie rośnie, szczególnie od początku tego wieku. Współczynniki umieralności od pięćdziesięciu lat pozostają na stałym poziomie.

Wprowadzenie testu klinicznego (PSA) do populacyjnego badania każdego mężczyzny w wieku powyżej 60-70 lat bez wcześniejszego wykonanego na dużej populacji naukowego badania epidemiologicznego doprowadziło najpierw w USA, a następnie w wielu innych krajach do tzw. epidemii rozpoznawania nowotworów prostaty. Zjawisko to dobrze ilustruje rycina 14, pokazująca gwałtowny wzrost zachorowań $z$ powodu tego schorzenia w latach 80 . XX wieku w USA. Obecnie dość powszechnie uważa się, że przyczyną tego zjawiska jest tzw. nadrozpoznawalność (overdiagnosis) ${ }^{13,14,15,16,17}$, czyli rozpoznanie guzów nowotworowych, które nigdy nie doprowadziłyby do wystąpienia objawów klinicznych (The detection of cancer that would never have becouse clinically evident), przy czym trzeba przypomnieć, że celem badań przesiewowych nie jest samo w sobie wykrycie nowotworu, ale zapobieganie zgonom z powodu nowotworów. Dlatego jedynym miernikiem skuteczności skriningu populacyjnego jest zmniejszenie wartości współczynników umieralności (częstości zgonów).

Problem nadrozpoznawalności dotyczy wszystkich rozwiniętych krajów, które prowadzą populacyjny skrining. Na podobną skalę wystąpiło w ostatnich latach zjawisko nadrozpoznawalności nowotworów tarczycy w Korei Południowej ${ }^{18}$. W latach 90. wprowadzono w tym kraju narodowy program badań przesiewowych w kierunku wykrywania nowotworów tarczycy. Wartość współczynnika zachorowalności na raka brodawkowatego tarczycy w 2011 r. była 15-krotnie wyższa niż w roku 1993. Nowotwór złośliwy tarczycy stał się w Korei nowotworem nr 1; rocznie diagnozowano ponad 40000 nowych zachorowań (populacja całego kraju to około 70 milionów). W tym samym czasie współczynniki umieralności z powodu nowotworów złośliwych tarczycy pozostawały na tym samym poziomie — rocznie obserwowano 300-400 zgonów.

Nadrozpoznawalność staje się kluczowym elementem onkologii wymagającym interpretacji epidemiologicznej opartej na dowodach (evidence and science based).

\footnotetext{
${ }^{13}$ Welch GH, Black WC. Overdiagnosis in cancer. J Natl Cancer Inst 2010; 102: 605-613.

${ }^{14}$ Jørgensen KJ, Gøtzsche PC. Overdiagnosis in publicly organised mammography screening programmes: systematic review of incidence trends. BMJ 2009; 339: b2587.

${ }^{15}$ Nagadowska MM. Skryning mammograficzny — fakty i kontrowersje. Medycyna Praktyczna 2011; 5: 56-60.

${ }^{16}$ Alvarado M, Ozanne E, Esserman L. Overdiagnosis and overtreatment of breast cancer. Am Soc Clin Oncol Educ Book 2012: e40-5.

${ }^{17}$ Bleyer MD, and Welch HG. Effect of three decades of screening mammography on breast-cancer incidence. N Engl J Med 2012; 367 1998-2005.

${ }^{18} \mathrm{Ahn} \mathrm{HS}$, Kim HJ, Welch HG. Korea's thyroid-cancer "epidemic" — screening and overdiagnosis. N Engl J Med 2014; 371: 1765-1767.
} 


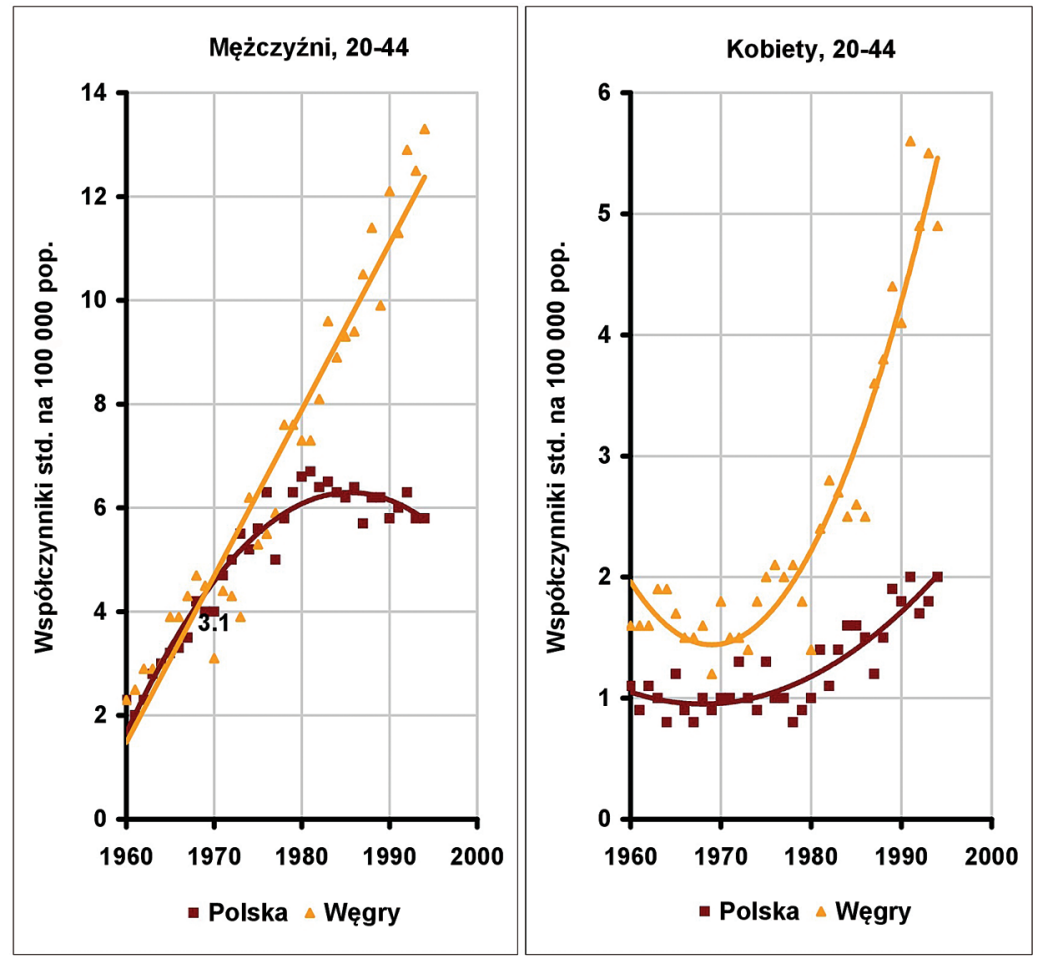

Rycina 11. Trendy czasowe standaryzowanych według wieku współczynników umieralności z powodu nowotworów złośliwych płuca w Polsce i na Węgrzech

Współczynniki standaryzowane zostały obliczone w oparciu o standardową populację świata Trendy czasowe umieralności z powodu nowotworów złośliwych płuca u młodych dorosłych mężczyzn w Polsce i na Węgrzech w latach 60. i 70. przebiegały identycznie. W latach dziewięćdziesiątych (po rozpoczęciu interwencji przeciwtytoniowej w Polsce) trendy rozeszły się. Na Węgrzech częstość nowotworów złośliwych płuca osiągnęła jedną z najwyższych obserwowanych na świecie wartości; w Polsce rozpoczął się trend spadku. U kobiet współczynniki na Węgrzech osiągnęły prawie trzy razy wyższy poziom niż w Polsce.

\section{Nowotwory jelita grubego}

Nowotwory jelita grubego są trzecim najczęstszym nowotworem u mężczyzn i drugim u kobiet. W 2012 roku zachorowało prawie 17 tys. osób (ok. 9,5 tys. mężczyzn i 7,5 tys. kobiet). Zachorowalność na nowotwory jelita grubego charakteryzuje się rosnącą tendencją u obu płci, przy czym u mężczyzn jest około dwukrotnie wyższa. W 2012 r. liczba zgonów z powodu nowotworów złośliwych jelita grubego wynosiła łącznie ponad 11,2 tys., w tym u mężczyzn ponad 6,1 tys., a u kobiet ponad 5,1 tys. zgonów.

Trend czasowy zachorowalności i umieralności bardzo różni Polskę od krajów zachodnich Unii Europejskiej (ryc. 15). Dobrym znakiem jest to, że po raz pierwszy w ostatnim dziesięcioleciu pojawiły się tendencje spadkowe umieralności wśród kobiet i zatrzymanie wzrostu umieralności mężczyzn. Szybki postęp w kontroli nowotworów złośliwych jelita grubego jest możliwy tylko poprzez zorganizowany narodowy program wczesnej diagnostyki i leczenia. Obecnie realizacja programu wczesnej diagnostyki nowotworów jelita grubego znajduje się we wczesnym etapie przygotowania do jego populacyjnej realizacji. Dokonano ogromnego postępu w szkoleniu lekarzy i personelu medycznego. Ośrodki specjalistyczne wyposażono w niezbędny sprzęt i wdrożono pilotowy program w wielu regionach Polski. Prowadzone w Polsce prace w tym zakresie uzyskały bardzo pozytywny odbiór ze strony międzynarodowego środowiska naukowego $^{19,20}$. Pełny program skriningowy w kierunku wykrywania nowotworów złośliwych jelita grubego w skali populacyjnej wymaga jednak uruchomienia znacznie większych środków i powołania organizacji do jego stałej realizacji, co zawarte jest w propozycji powołania Narodowego Instytutu Onkologii i Hematologii w Warszawie. Dopiero taki program i jego realizacja mogą doprowadzić do zmniejszenia umieralności z powodu nowotworów jelita grubego w Polsce ${ }^{21}$.

\section{Nowotwory szyjki macicy}

Nowotwory szyjki macicy są schorzeniem dość rzadkim. W 2012 roku zachorowało na nie około 2,8 tys. kobiet, a zmarło około 1,7 tys. Ze względu jednak na dużo większe zagrożenie w Polsce na tle innych krajów europejskich i możliwości zapobiegania temu schorzeniu, przy pełnej wiedzy o jego etiologii, wczesnej diagnostyce i eradykacji (poprzez szczepienia), schorzenie to jest szczególnie uważnie monitorowane jako wyznacznik stanu zdrowia publicznego.

Zachorowalność na nowotwory złośliwe szyjki macicy spada w Polsce od lat 80. ubiegłego wieku, a ostatnia dekada przyniosła przyspieszenie tego spadku. Umieralność z tego powodu wykazuje również długoletnią tendencję malejącą (ryc. 16).

Populacyjny skrining nowotworów złośliwych szyjki macicy doprowadził do konsolidacji istotnego spadku współ-

\footnotetext{
${ }^{19}$ Reguła J, Rupinski M, Kraszewska E i wsp. Colonoscopy in colorectal cencer screening for detection of advanced neoplasia. N Engl J Med 2006; 355: 1863-1872.

${ }^{20}$ Kamiński MF, Reguła J, Kraszewska E i wsp. Quality indicators for colonoscopy and the risk of interval cancer. N Engl J Med 2010; 362: 1795-1803.

${ }^{21}$ Zatoński WA. Powołanie Narodowego Instytutu Onkologii i Hematologi - warunek konieczny do skutecznej walki z rakiem w Polsce. Nowotwory
} J Oncol 2013; 63: 375-381. 

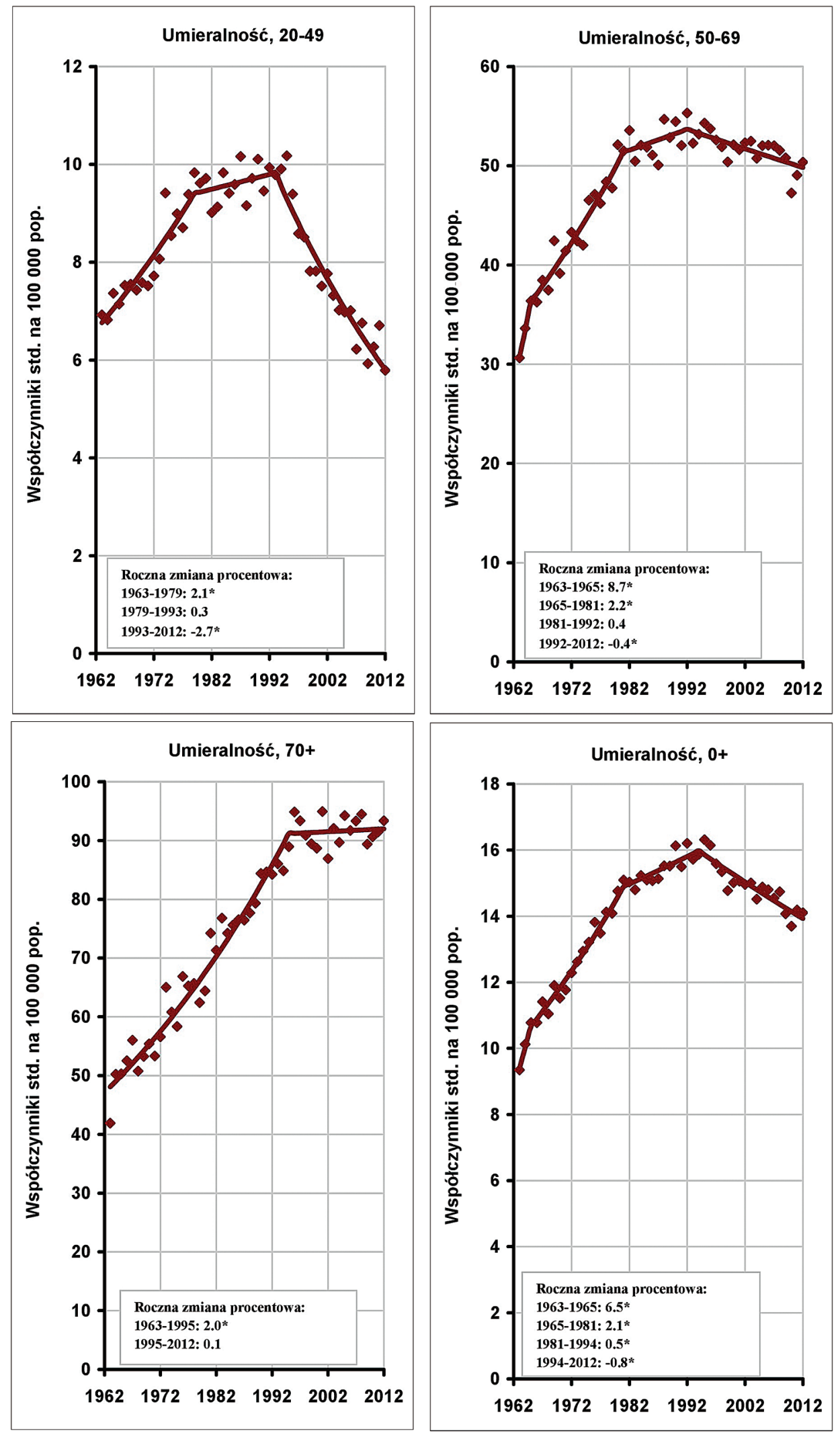

Rycina 12. Trendy czasowe standaryzowanych według wieku współczynników umieralności z powodu nowotworów złośliwych piersi w Polsce Współczynniki standaryzowane zostały obliczone w oparciu o standardową populację świata

*Zmiana istotnie statystycznie różna od zera.

Od pewnego czasu obserwuje się w Polsce zatrzymanie wzrostu umieralności z powodu nowotworów złośliwych piersi we wszystkich grupach wieku. Znamienny spadek współczynników umieralności dotyczy przede wszystkim najmłodszej grupy wieku. 


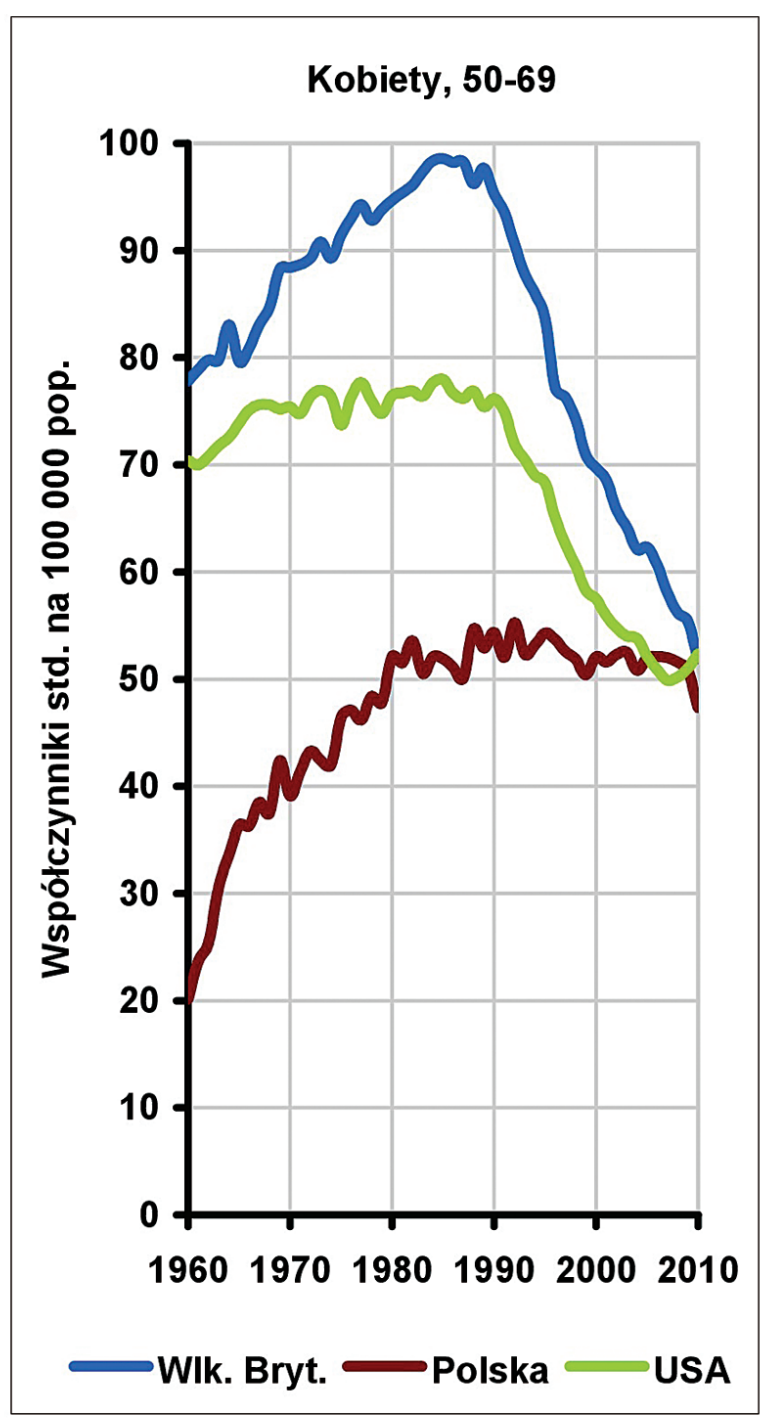

Rycina 13. Trendy czasowe standaryzowanych według wieku współczynników umieralności z powodu nowotworów złośliwych piersi w wybranych krajach

Współczynniki standaryzowane zostały obliczone w oparciu o standardową populację świata

Od początku lat 90. obserwuje się w Wielkiej Brytanii i USA spadek umieralności z powodu nowotworów złośliwych piersi u kobiet w średnim wieku. Spadek ten jest znaczący, stały i równomierny. Mimo że także w Polsce został zatrzymany wzrost umieralności, ciągle nie obserwuje się porównywanego z UK tempa spadku współczynników umieralności (umieralność w UK zmniejszyła się o połowę w ciągu ostatnich 30 lat).

Czynników umieralności z powodu nowotworów szyjki macicy we wszystkich grupach wiekowych i we wszystkich regionach Polski. Poziom umieralności jest stale wyższy niż w krajach zachodnich Unii (ryc. 17), ale, co warto też przypomnieć, niższy niż w wielu sąsiednich krajach, np. krajach bałtyckich. Największym wyzwaniem w kontroli nowotworów złośliwych szyjki macicy w Polsce jest znikomy udział w skriningu gorzej wykształconych i słabiej sytuowanych kobiet, często mieszkanek małych miejscowości i wiosek. Konieczne jest stworzenie programów, które doprowadzą do zmniejszenia liczby kobiet, które nigdy nie uczestniczyły w badaniu (obecnie to około 20\% w grupie wieku 25-59 lat).

\section{Nowotwory żołądka}

Nowotwory złośliwe żołądka dzięki trwałemu spadkowi zachorowalności i umieralności u obu płci stały się obecnie piątym u mężczyzn i ósmym u kobiet nowotworem i odpowiednio czwartą i szóstą przyczyną zgonu. W 2012 roku na nowotwory złośliwe żołądka zachorowało ponad 5,4 tys. osób: prawie 3,5 tys. mężczyzn i 2 tys. kobiet, a zmarło z tej przyczyny ponad 5,3 tys. osób, w tym ok. 3,5 tys. mężczyzn i ponad 1,8 tys. kobiet.

Przez cały XX wiek we wszystkich krajach europejskich obserwuje się stałe zmniejszanie się zachorowalności oraz wynikającej z tego umieralności z powodu nowotworów złośliwych żołądka. Sukces ten jednak nie był wynikiem zaplanowanych, racjonalnych działań człowieka, a raczej „produktem ubocznym” naszego rozwoju cywilizacyjnego. Przykład nowotworu żołądka pokazuje, że określanie nowotworów chorobami cywilizacyjnymi jest nietrafne. Rozwój cywilizacyjny może także być czynnikiem zmniejszającym zagrożenie tymi schorzeniami, a problemy z nowotworami złośliwymi piersi czy żołądka są tak stare jak ludzkość.

Nowotwór żołądka był historycznie najczęstszym nowotworem złośliwym w populacji Polski. Aż do początku lat 70. XX wieku pozostawał on najczęstszym nowotworem złośliwym tak u mężczyzn, jak i u kobiet ${ }^{22,23}$. Od tego czasu ryzyko zachorowania na tego typu nowotwory zmniejszyło się w Polsce wielokrotnie (ryc. 18). Interesującym faktem jest, że trend czasowy umieralności z powodu nowotworów złośliwych żołądka zarówno u kobiet, jak i u mężczyzn jest prawie identyczny jak w Austrii (ryc. 19), natomiast różni się znacznie od trendów obserwowanych w krajach śródziemnomorskich ${ }^{24,25}$. Należy przy tym zwrócić uwagę, że do początku drugiej dekady XXI wieku nie osiągnięto przełomu w leczeniu tego schorzenia. Wydaje się, że częstość występowania tego nowotworu będzie w najbliższych dziesięcioleciach dalej stale się zmniejszała.

\footnotetext{
${ }^{22}$ Zatoński W. Stomach — ICD 151. W: Zatoński W, Becker N. Atlas of cancer mortality in Poland, 1975-1979, Springer Verlag, Heidelberg, 1988, s. 34-41. ${ }^{23} Z$ Zatoński W. Nowotwory złośliwe żołądka. W: Zatoński W. Nowotwory złośliwe w Polsce. Centrum Onkologii-Instytut, Warszawa, 1993, s. 25-33. ${ }^{24}$ Zatoński W, Smans M, Tyczyński J, Boyle P. Atlas of cancer mortality in Central Europe. IARC Scientific Publications No. 134 International Agency for Research on Cancer Lyon, France 1996.

${ }^{25}$ Howson CP, Hiyama T, Wynder El. The decline in gastric cancer: epidemiology of an unplanned triumph. Epidemiol Rev 1986; 8: 1-27.
} 


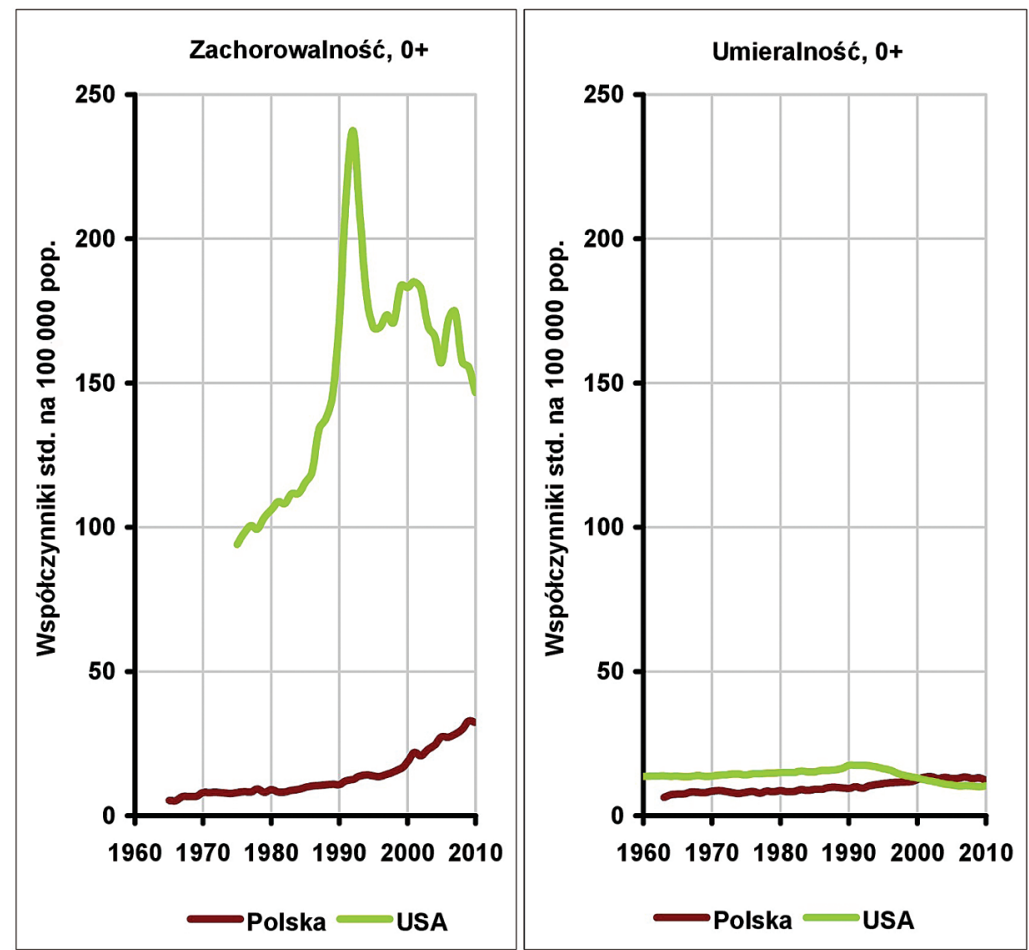

Rycina 14. Trendy czasowe standaryzowanych według wieku współczynników zachorowalności i umieralności z powodu nowotworów złośliwych gruczołu krokowego w Polsce i USA

Współczynniki standaryzowane zostały obliczone w oparciu o standardową populację świata

W latach 80. XX wieku, po wprowadzeniu na populacyjną skalę badania PSA, obserwowano w USA gwałtowny wzrost nowo

rozpoznawanych nowotworów prostaty. W krótkim okresie nowotwory prostaty stały się tam najczęściej rozpoznawanym nowotworem u mężczyzn. Wzrost rozpoznawanych nowotworów gruczołu krokowego nie wpłynął na poziom umieralności z powodu tych nowotworów.

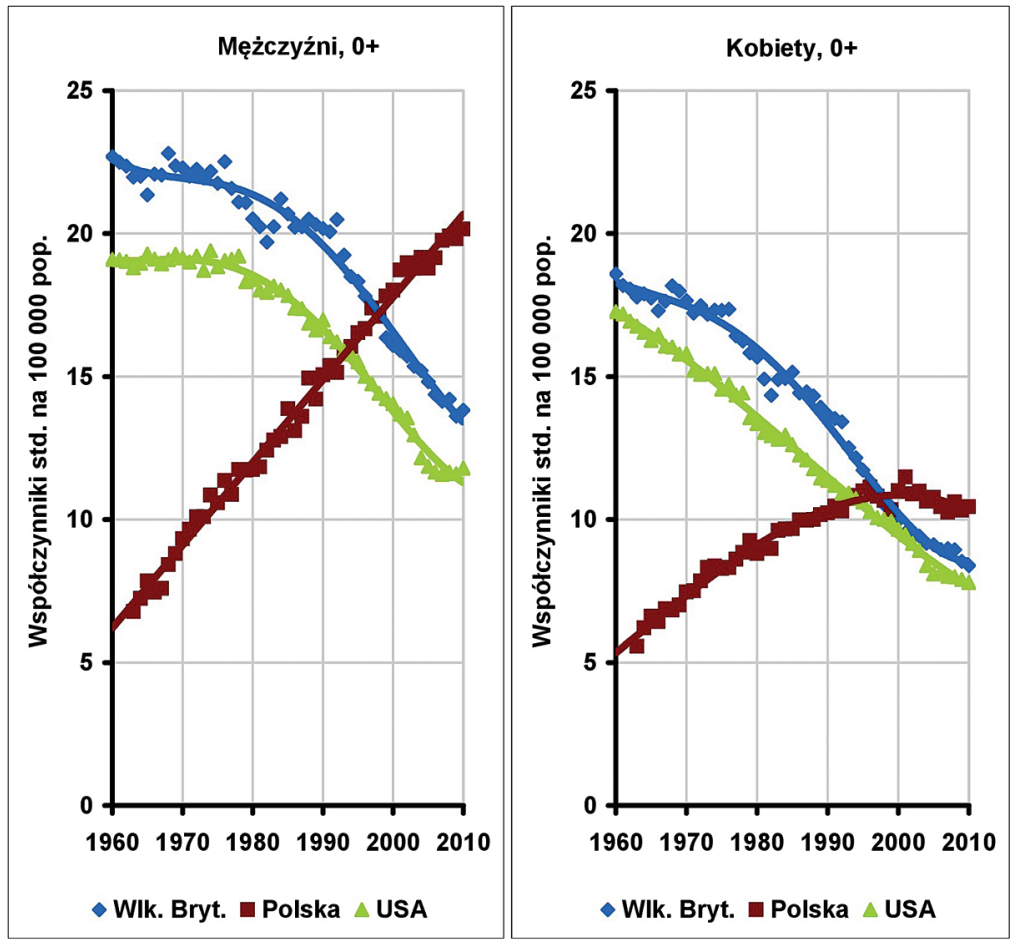

Rycina 15. Trendy czasowe standaryzowanych według wieku współczynników umieralności z powodu nowotworów złośliwych jelita grubego w wybranych krajach

Współczynniki standaryzowane zostały obliczone w oparciu o standardową populację świata

W Polsce stale utrzymuje się wzrost umieralności z powodu nowotworów złośliwych jelita grubego, szczególnie u mężczyzn. W tym samym czasie w Wielkiej Brytanii i USA występuje istotny spadek umieralności z tej przyczyny, zarówno u kobiet, jak i u mężczyzn. 


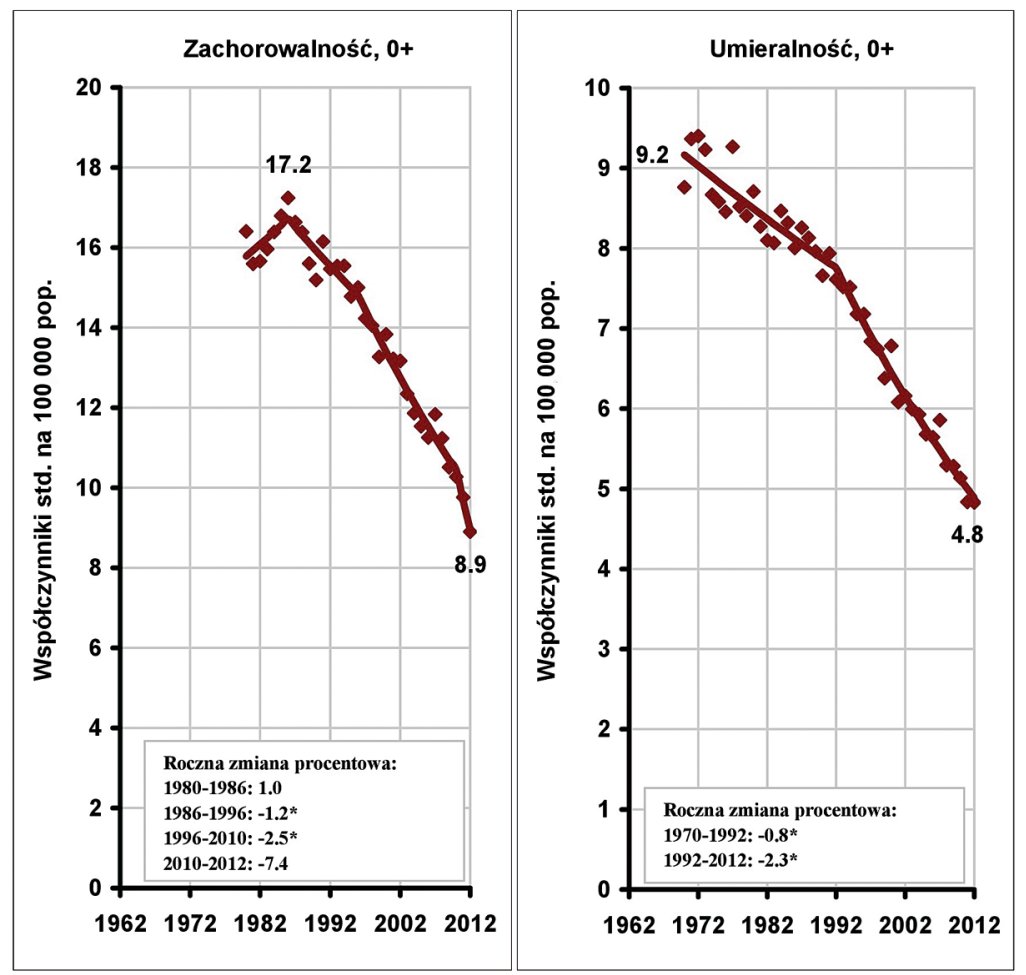

Rycina 16. Trendy czasowe standaryzowanych według wieku współczynników zachorowalności i umieralności z powodu nowotworów złośliwych szyjki macicy w Polsce

Współczynniki standaryzowane zostały obliczone w oparciu o standardową populację świata Niedorejestrowanie zachorowań na nowotwory złośliwe w Polsce szacowano na $30 \%$ na początku lat 80., a w 2011 r. niedorejestrowanie w skali kraju wyniosło 6\%. (Źródło: Didkowska J, Wojciechowska U, Zatoński W. Nowotwory złośliwe w Polsce w 2011 roku. Warszawa: Krajowy Rejestr Nowotworów, Centrum Onkologii — Instytut im. Marii Skłodowskiej-Curie; 2013). *Zmiana istotnie statystycznie różna od zera. W Polsce obserwuje się istotny spadek zachorowalności i umieralności na nowotwory złośliwe szyjki macicy.

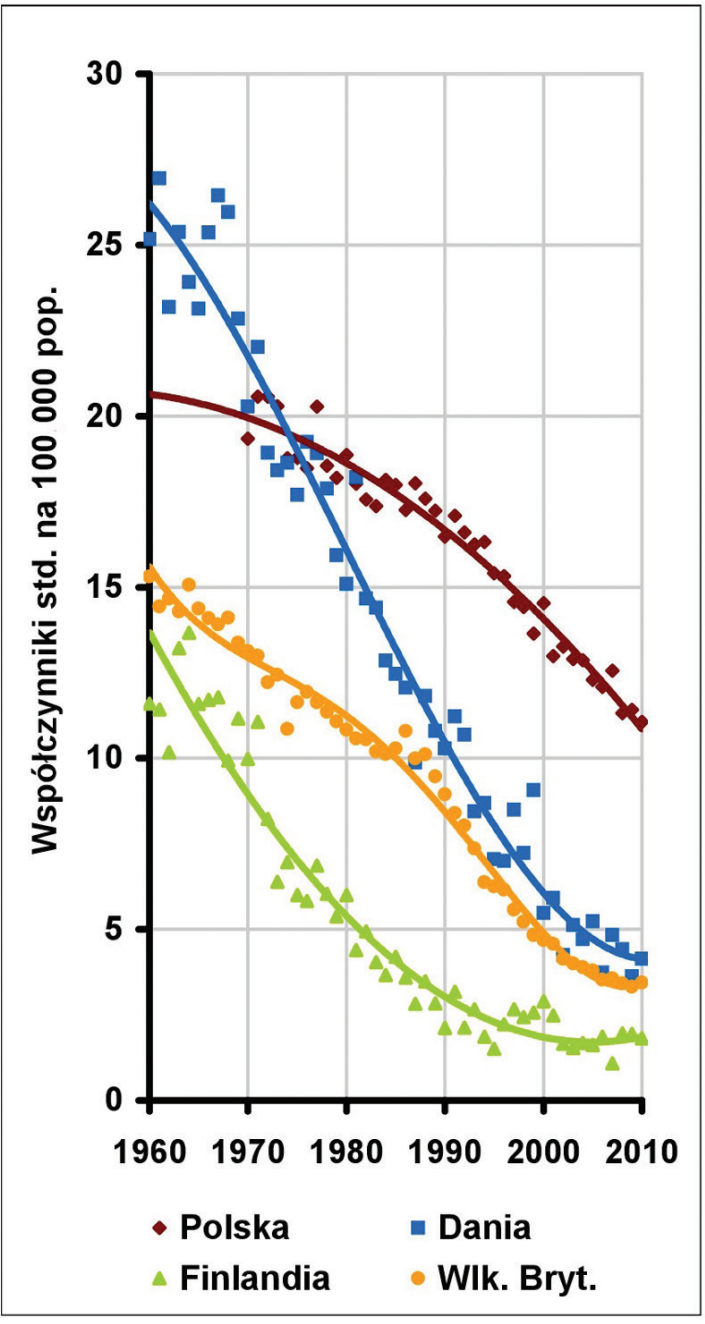

Rycina 17. Trendy czasowe standaryzowanych według wieku współczynników umieralności z powodu nowotworów złośliwych szyjki macicy wśród kobiet w wieku 30-74 lat w wybranych krajach Współczynniki standaryzowane zostały obliczone w oparciu o standardową populację świata

Spadek umieralności z powodu nowotworów złośliwych szyjki macicy wśród kobiet w wieku 30-74 lat jest znacznie szybszy w Danii, Finlandii czy Wielkiej Brytanii niż w Polsce, przez co pod koniec pierwszej dekady XXI wieku obserwuje się w tych krajach znacznie niższy poziom umieralności z tej przyczyny niż w Polsce. Umieralność z powodu nowotworów złośliwych szyjki macicy w Polsce należy do najwyższych w Europie. 

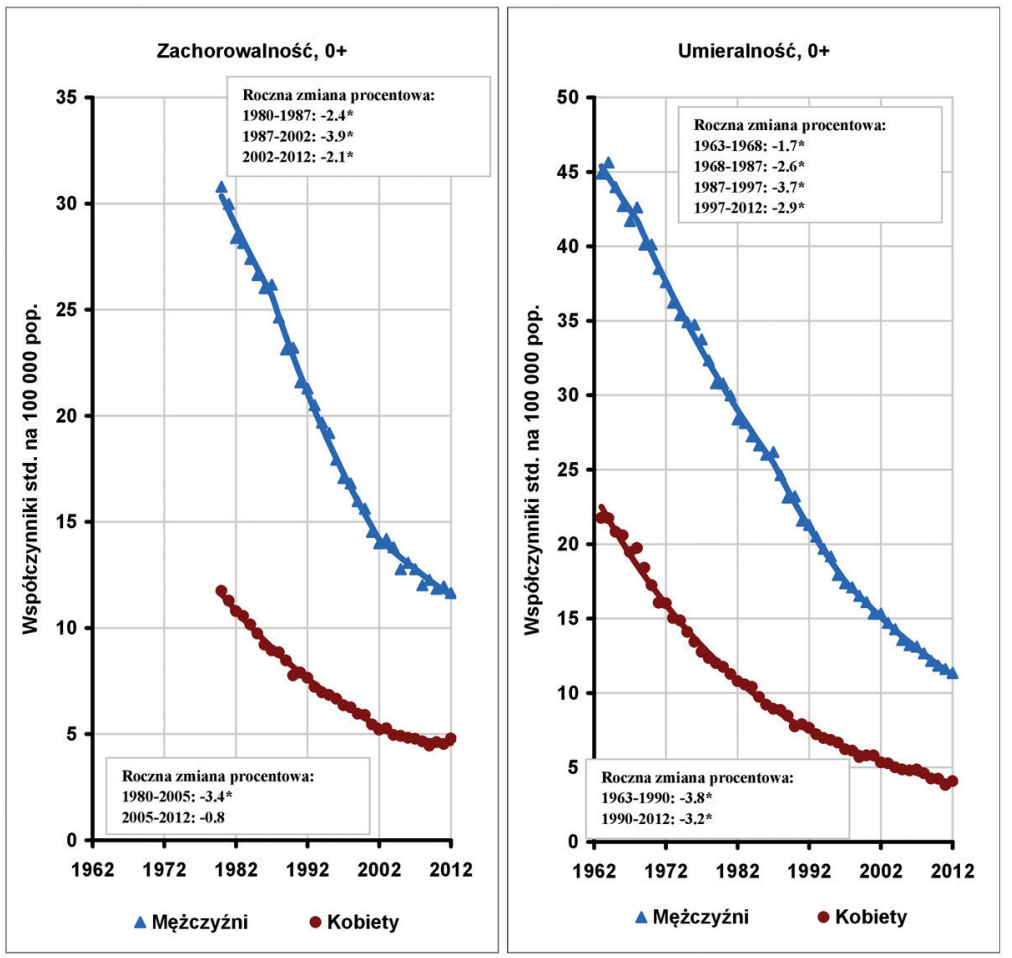

Rycina 18. Trendy czasowe standaryzowanych według wieku współczynników zachorowalności i umieralności z powodu nowotworów złośliwych żołądka w Polsce

Współczynniki standaryzowane zostały obliczone w oparciu o standardową populację świata Niedorejestrowanie zachorowań na nowotwory złośliwe w Polsce szacowano na $30 \%$ na początku lat 80., a w 2011 r. niedorejestrowanie w skali kraju wyniosło 6\%. (Źródło: Didkowska J, Wojciechowska U, Zatoński W. Nowotwory złośliwe w Polsce w 2011 roku. Warszawa: Krajowy Rejestr Nowotworów, Centrum Onkologii — Instytut im. Marii Skłodowskiej-Curie; 2013).

*Zmiana istotnie statystycznie różna od zera.

Trendy czasowe zachorowalności i umieralności z powodu nowotworów złośliwych żołądka w Polsce, zarówno u mężczyzn, jak i u kobiet, wykazują tendencję spadkową.
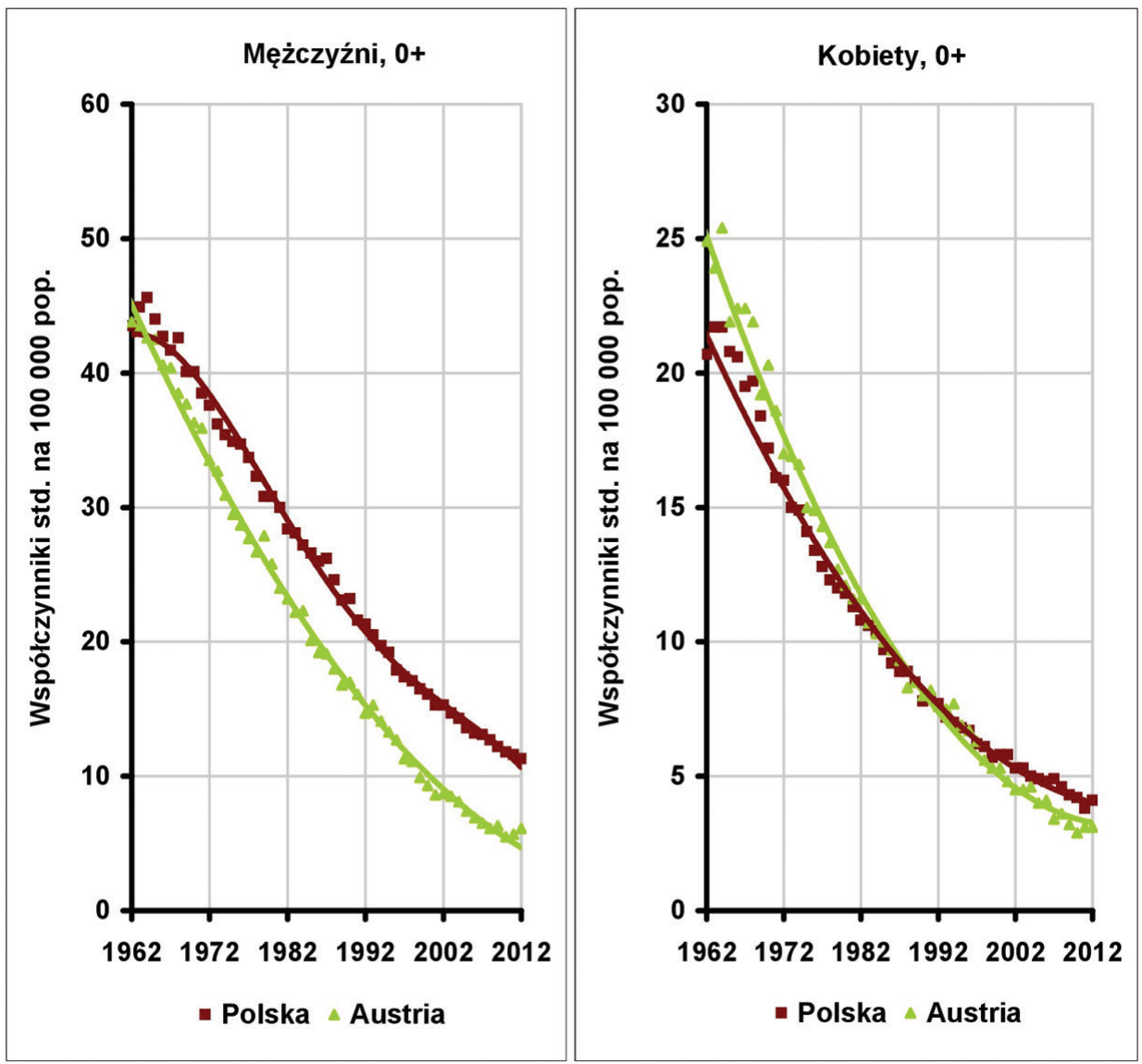

Rycina 19. Trendy czasowe standaryzowanych według wieku współczynników umieralności z powodu nowotworów złośliwych żołądka w Polsce i Austrii

Współczynniki standaryzowane zostały obliczone w oparciu o standardową populację świata

Tempo spadku umieralności z powodu nowotworów złośliwych żołądka w Polsce i Austrii jest podobne, szczególnie u kobiet. 


\section{Podsumowanie}

Wykonana analiza epidemiologiczna legitymizuje wnioski, które zostały przedstawione w publikacji: Zatoński WA. Powołanie Narodowego Instytutu Onkologii i Hematologii - warunek konieczny do skutecznej walki z rakiem w Polsce. Nowotwory J Oncol 2013; 63: 375-381.

„Reasumując, po 8 latach funkcjonowania NPZChN doprowadził do głębokich zmian w funkcjonowaniu wczesnej diagnostyki ileczenia nowotworowego w tych lokalizacjach, gdziejest to możliwe. Jego realizacja, co oczywiste, musi być dalej pogłębiana i wymaga także budowania kompetencji społeczeństwa (walka z analfabetyzmem w zakresie nowotworów) oraz jego gotowości do uczestniczenia w programie, obok rozbudowy infrastruktury. Program musi byćkonsekwentnie realizowany (co nie znaczy, że nie wymaga także fundamentalnych zmian wynikających z postępu wiedzy medycznej) przez następne dziesięciolecia. Dlatego też istniejq ważne przyczyny, dla których Centrum Onkologii i sieć regionalnych centrów onkologii muszq być ważnymi uczestnikami tworzenia kolejnego planu walki rakiem na lata 2016+. Nowy program nie może byćzlepkiem wynikającym z nacisków różnych instytucji i grup ani być tworzony pod wpływem emocji, ale musi wynikać z medycyny opartej na dowodach (science-and-evidence based) irachunku ekonomicznym. Program musi także być realizowany w taki sposób, aby uwzględniał najbardziej zagrożonych chorobami nowotworowymi (to jest gorzej wykształconych i sytuowanych). Jego realizacja musi być transparentna, programowana i kontrolowana przez niezależne ciała zawodowe, społeczne i polityczne".

Prof. dr hab. n. med. Witold A. Zatoński

Zakład Epidemiologii i Prewencji Nowotworów Centrum Onkologii — Instytut im. Marii Skłodowskiej-Curie ul. W.K. Roentgena 5, 02-781 Warszawa

e-mail:zatonskiw@coi.waw.pl 